\title{
THE INCIDENCE OF PELLAGRA IN SPARTANBURG COUNTY, S. C., AND THE RELATION OF THE INITIAL ATTACK TO RACE, SEX AND AGE*
}

\author{
J. F. SILER, M.D., P. E. GARRISON, M.D. \\ AND \\ W. J. MACNEAL, M.D. \\ NEW YORK
}

\section{INTRODLCTION}

The extensive records accumulated during the field study of pellagra in Spartanburg County, S. C., have presented an opportunity to inquire into the behavior of this disease in a population of considerable size living under natural conditions of civil life. Such an inquiry might be expected to contribute something to the general prognosis of pellagra in the population of the county and in the Southern states as a whole and it might even bring to light some facts of value in the prognosis in an individual case of the disease. Manifestly, also, it is desirable to know fairly well the course of the disease as a biological phenomenon, uninfluenced by intentional drugging, dieting or climatic changes, in order to estimate the possible influence which these latter may exert on the course of pellagra. Fortunately for the purpose of such a study, a considerable proportion of the pellagrins of our series have received no particular treatment directed against the disease; in fact, many had suffered from pellagra for years without the nature of the ailment being recognized. The recorded material is rich in possibilities of analysis. It seems wisest to direct attention to certain specific points, one at a time. Many important facts in regard to these cases will be found recorded and discussed in other papers of this series, constituting our third report, and also in the preceding first and second progress reports of this commission.

In the present paper we purpose to present the recorded facts in respect to incidence of pellagra and its death rate in the year of initial attack in each year since the appearance of the earliest recognized case in the county and the correlations between race, sex and age on the

\footnotetext{
* Submitted for publication April 3, 1916.

* From the Robert M. Thompson Pellagra Commission of the New York Post-Graduate Medical School and Hospital.

* The final copy of this paper has been written since Dr. Garrison and Dr. Siler were recalled to active duty in the Medical Corps, U. S. Navy, and the Medical Corps, U. S. Army, respectively. Although they are quite familiar with the general nature of the paper and with the conclusions, they are not personally responsible for the detailed compilation of data or for the specific deductions drawn from them.
} 
one hand, and incidence of pellagra and death rate in initial attack on the other, as shown by the total cases on our records at the end of the field work in 1914. In subsequent papers we purpose to consider the tendency to recurrence, death rate in recurrence and tendency to recovery.

The present paper deals only with incident, or initial attacks, of pellagra and not with recurrences of the disease, a sharp distinction being made between incident, or first attack, and subsequent, or recurrent attack, of the disease.

\section{INCIDENCE OF I'ELLAGRA IN EACII YEAR}

In all cases of our series subsequent to 1907 , we have arrived at a decision concerning the year in which the first erythema appeared, but we do not wish to maintain that these decisions are in every case correct. For those cases originating previous to 1908 it has not been possible to arrive at a decision in all instances. Of the 1,180 recognized pellagrins on our records at the end of 1914, there are fifty-seven cases in which the initial erythema appeared before 1908. The available evidence indicates with considerable certainty that the initial attacks appeared in these patients in the different years as shown in Table 1 .

TABle 1.-Distribution of Cases of Pellagra Incident Before 1908, According to Ykak of Onset of The First Erythema

Year..... 18881889189018911892189318941895189618971898189919001901190219031904190519061907 Uncertain Total

$\begin{array}{lllllllllllllllllllllll}\text { Patients. } & 1 & 0 & 0 & 0 & 1 & 1 & 2 & 0 & 0 & 0 & 1 & 0 & 3 & 3 & 2 & 6 & 5 & 10 & 6 & 14 & 2 & 57\end{array}$

Concerning those pellagrins who suffered their first attack in 1908 , 1909,1910 or 1911, we have somewhat more reliable information, because during these years the physicians of the county were already acquainted with the disease, but it is still probable that the list of cases is very far from complete, more particularly in the earlier years. The recorded statistics for 1912, 1913 and 1914, and probably also for 1911, are distinctly more reliable and complete and probably approach very nearly the degree of accuracy attainable in field work of this sort, because of our presence in the field during 1912, 1913 and 1914 . We are inclined to regard the recorded statistics for 1912 as somewhat more complete than those for 1914, because the observations made in 1912 have been added to by further observations during two subsequent years. The incidence of pellagra in each year subsequent to 1907 is shown in Table 2 and the data are presented graphically in Figure 1.

TABle 2.-Distribution of Total Recorded Pellagrins According to Year of ONSET of First ERYThema

$\begin{array}{cccccccccc}\text { Year.............. Before } 1908 & 1908 & 1909 & 1910 & 1911 & 1912 & 1913 & 1914 & \text { Total } \\ \text { Patients........... } & 57 & 20 & 57 & 141 & 234 & 211 & 251 & 209 & 1,180\end{array}$


The recorded data indicate that the number of new cases each year has increased rapidly from 1908 to 1911, and that the incidence rate has changed but little from 1911 to 1914. These indications may be questioned to some extent. We are inclined to accept the indication of an actual rapid increase from 1908 to 1911 in the number of individuals newly attacked by pellagra, but we think that the magnitude

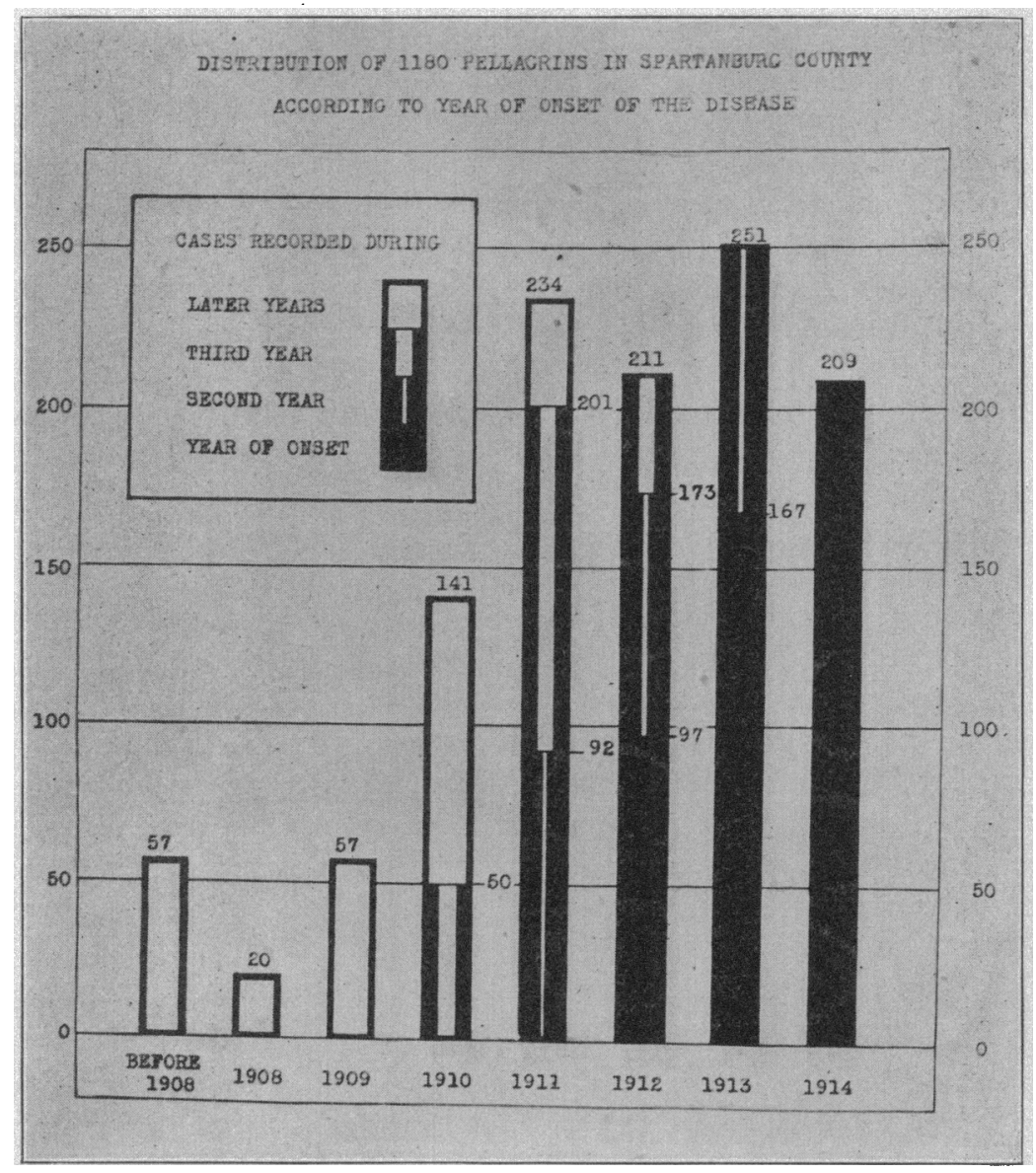

Fig. 1.-The total height of each column indicates the total number of new cases of pellagra in the respective year, according to our records at the end of 1914. The height of the solid black column indicates the number of new cases recognized and recorded by us during the year in which the disease began. For 1914 the whole column is, of course, solid black.

of this increase is somewhat exaggerated in the table because of relatively incomplete records for the earlier years. In other words, we are actually convinced that there were very many more new cases of pellagra in Spartanburg County in 1911 than in 1908, probably at least 
four times as many, but the indicated elevenfold increase appears too large. In the statistics of cases originating subsequent to 1911 another factor of error assumes prominence. This depends in part on the evident tendency of many pellagrins to conceal their disease until it recurs once or even twice, and in part on the necessary incompleteness of our survey of the county in each year, as a result of which many incident cases, especially those arising later in the season, escaped discovery during the year of the initial attack. Thus, at the end of 1912, our first year in the field, we had recorded only ninety-two cases which originated in 1911 ; at the end of 1913 this number had been augmented to 201 , and at the end of 1914 it had been further increased to a total of 234. In a similar way the number of pellagrins with onset in 1912 who had been recognized and recorded at the end of 1912 was only ninety-seven; in 1913 there were added seventy-six, making 173, and during 1914 there were discovered thirty-eight more pellagrins with onset in 1912, augmenting the total to 211. The number of patients with onset in 1913 recognized and recorded during 1913 was 167 , and in 1914 we added eighty-four to this number, making a total of 251 with initial attack in 1913 . If, therefore, one should compare the total recorded pellagrins incident in 1914 with the analogous figures for 1912 and 1913, as the figures stood at the end of the field work of the respective years, a very considerable increase in the new cases of pellagra would be indicated, namely, from 97 to 167 to 209 for 1912, 1913 and 1914, respectively. We are not inclined to regard these figures as a true measure of the increase in new cases of the disease in the last few years, for it is doubtless true that the data obtained in 1914 are more complete than those obtained in previous years, because of the greater experience of the observers and more thorough acquaintance with the field of work, but in this connection it should be mentioned that our field work ended on Oct. 15, 1914, and necessarily many portions of the county had not been visited for several weeks previous to that time. Judging from the experience of earlier years, it seems assured that further systematic field work in 1915 and 1916 would bring to light from sixty to eighty additional cases of pellagra which had their onset in 1914.

The year 1911 merits special consideration because of the relatively excessive number of pellagrins recorded as having the initial attack in that year. It is possible that some cases which actually originated earlier have been placed in 1911, because of the widely awakened interest in pellagra in Spartanburg County during this year. Dr. R. M. Grimm ${ }^{1}$ made an epidemiologic survey of certain portions of this county in 1911, and there can be no doubt but that his presence and the

1. Grimm, R. M.: Pellagra : a Report on Its Epidemiology, U. S. Pub. Health Rep., 1913, xxviii, 427, 491. 
stimulus of his work brought to light many cases not previously recognized, although the disease had actually originated earlier in these patients. On the other hand, many physicians who have been practicing in the region for many years have expressed the opinion that 1911 was an exceptional year for pellagra and that a disproportionately large number of new cases actually did arise in that year, not only in many parts of Spartanburg County, but also in neighboring counties. This opinion possesses some weight and lends support to the indication of high incidence in 1911 shown by the recorded statistics.

From a consideration of these various sides of the question, we have arrived at the conclusion that the number of new cases of pellagra in Spartanburg County has been increasing somewhat, probably about 10 per cent. per year on the average, during the last three or four years, and that the increase previous to 1911 was at a more rapid rate.

\section{DEATHS DURING THE YEAR OF INITIAL ATTACK}

For the purpose of this study we have arbitrarily decided to consider a death which occurred previous to February 1 of the year following the initial erythema as a death in the first attack of pellagra. In many instances it has been impossible for us to estimate the relative importance as a cause of death of the pellagra as compared with other diseases from which the patient may have been suffering, and therefore unless it has been perfectly clear that death resulted without relation to pellagra the death has been included as due to this disease.

Of the total 1,180 recorded pellagrins, 187 died during the year of initial attack, as defined in the preceding paragraph, indicating a death rate in the first attack amounting to 15.8 per cent. This figure is undoubtedly too high rather than too low, because in pellagra, as fo: vital statistics in general, mortality reports tend to be more complete than morbidity reports, however much care be devoted to the matter. Doubtless, also, some of these deaths occurred during a year subsequent to that of the initial erythema, the latter having escaped observation and record.

The deaths in initial attack include, as previously stated, those deaths which occurred up to February 1 following the year of initial erythema, in addition to those which occurred in the respective year. Their distribution by years is shown in Table 3 .

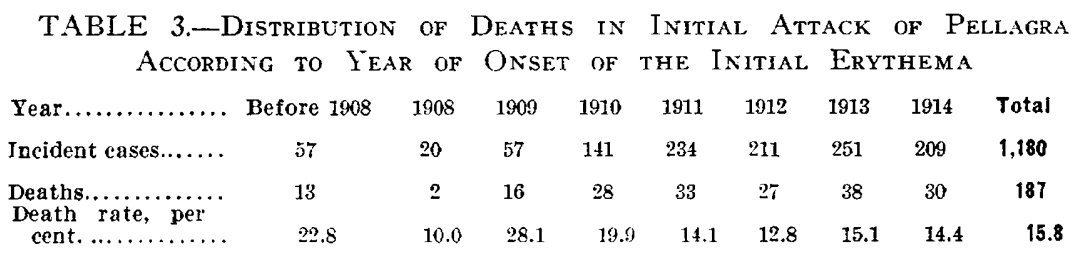


The gross indicated death rate, 15.8 per cent., is after all not so very much greater than the rate calculated for each of the last four years. One may conclude, therefore, that the death rate for pellagra in Spartanburg County has been between 10 and 16 per cent., and that there is no conclusive evidence that this death rate has increased or diminished progressively during the past four years. Previous to 1911 the death rate indicated by the records was considerably higher, but this indication should not be too readily accepted without some thought of the incompleteness of the data. It is not improbable that an appreciable number of those who died of pellagra in 1909 and 1910 may actually have had an unrecorded initial erythema in some previous year, so that they really died in a recurrence rather than in the first year of the disease.

RELATION OF PELLAGRA INCTDENCE TO RACE, SEX AND AGE

The important relations of age and sex to pellagra, as well as the racial distribution of the disease, have been discussed in our previous reports, more completely in the second progress report. ${ }^{2}$ It is our purpose to consider these relationships in greater detail in the much larger group of cases now available.

Of the total 1,180 recorded pellagrins, 1,026 were white and 153 were colored (including mixed blood), giving a ratio of 6.7 to 1 . This agrees well with the ratio shown in the previous report, cited above, upon the 780 cases recorded to the end of 1913, of which 680 were white and 100 colored, giving a ratio of 6.8 to 1 . The number of white persons and colored persons who suffered an initial attack of pellagra in each year subsequent to 1907 is indicated in Table 4. According to the available records the proportion of negro pellagrins was relatively less some years ago and has been increasing somewhat since 1911. Of the 509 recorded initial attacks up to the end of 1911, there were fifty-three, or 10.4 per cent., in colored persons, whereas, of the 671 cases originating since the end of 1911, no less than 100 , or 14.9 per cent., have been in the colored race.

TABle 4.-White and Colored Pellagrins Distributed According to the Year of INitial ERythema

$\begin{array}{lccccccccr}\text { Year............. } & \text { Before } 1908 & 1908 & 1909 & 1910 & 1911 & 1912 & 1913 & 1914 & \text { Total } \\ \text { White............ } & 51 & 20 & 53 & 123 & 209 & 182 & 213 & 176 & 1,027 \\ \text { Colored............ } & 6 & 0 & 4 & 18 & 25 & 29 & 38 & 33 & 153 \\ \text { Total............ } & 57 & 20 & 57 & 141 & 234 & 211 & 251 & 209 & 1,180 \\ \text { White, per cent.... } & 89.5 & 100.0 & 93.0 & 87.2 & 89.3 & 86.3 & 84.9 & 84.2 & 87.0 \\ \text { Golored, per cent. .. } & 10.5 & 0.0 & 7.0 & 12.8 & 10.7 & 13.7 & 15.1 & 15.8 & 13.0\end{array}$

2. Siler, Garrison and MacNeal: Statistics of Pellagra in Spartanburg County, S. C., The Archives Int. Med., 1915, xv, 98 ; Second Progress Report, 1915, 121. 
In our previous report it has been pointed out that the white population of Spartanburg County is about twice as numerous as the colored population, 57,048 and 26,410, respectively, according to the U. S. Census, 1910, so that the pellagra morbidity among negroes was only about one third of the morbidity rate for the white population. As we have previously stated, we regard this disparity not as evidence of racial resistance to pellagra on the part of negroes, but as a result of their different living conditions and partial social segregation from the inhabitants of the endemic foci of the disease. It now appears that this disparity is showing a slight tendency to become equalized, but that the negro race still remains very much less afflicted with pellagra. than the white race in Spartanburg County. The gradual relative increase of pellagra in the colored race in this county might be expected as the disease gradually extends more and more from its principal endemic foci in the mill villages out into the rural population.

The relationship between race and death rate from pellagra clearly indicates lesser resistance in the negro race, once the disease has been contracted. Of the 1,027 white pellagrins, 123, or 12 per cent., died in the year of the initial erythema (including the following January), whereas, of the 153 negro pellagrins, no less than sixty-four, or 41.8 per cent., died during the year of the initial erythema. In short, pellagra in Spartanburg County attacks members of the negro race less frequently, but it is far more fatal to them when they are attacked, a condition of affairs which finds analogy in many other diseases due to infection.

The high death rate in pellagra among negroes in the United States has been repeatedly observed. Searcy's early report ${ }^{3}$ indicated a high death rate among negroes in a hospital for the insane, namely, 64 per cent. Lavinder ${ }^{4}$ has published the statistics of reported cases and reported deaths in Mississippi from January to June, 1913. The ratio between number of reported deaths and number of reported cases in the white race was 74 to 648 , or 11.4 per cent., and the analogous ratio for the negro race was 194 to 665 , or 29.2 per cent.

The relationship between age and sex and the incidence of pellagra has been discussed in our previous reports. In the series of 1,180 cases now available, the relationships are similar in character to those previously found, but the larger number of cases now warrants the consideration of these questions in somewhat greater detail. In the present study each case has been tabulated according to age at onset of the initial erythema and the data are shown in Table 5. The distribution,

3. Searcy, George H.: An Epidemic of Acute Pellagra, Jour. Am. Med. Assn., 1907, xlix, 37.

4. Lavinder, C. H.: Pellagra in Mississippi, U. S. Pub. Health Rep., 1913, xxviii, 2035. 
TABle 5.-Distribytion of Pellagrins Accordingi to Race, Sex and Age. at Onset of First ERythema

\begin{tabular}{|c|c|c|c|c|c|c|c|c|c|}
\hline \multirow{2}{*}{$\begin{array}{l}\text { Age, } \\
\text { Years }\end{array}$} & \multicolumn{3}{|c|}{ White } & \multicolumn{3}{|c|}{ Colored } & \multicolumn{3}{|c|}{ Both Races } \\
\hline & Female & Male & Total & Female & Male & Total & Female & Male & Total \\
\hline $\begin{array}{l}0 \ldots \ldots \ldots \\
1 \ldots \ldots \ldots \ldots \\
2 \ldots \ldots \ldots \ldots \\
3 \ldots \ldots \ldots \\
4 \ldots \ldots \ldots\end{array}$ & $\begin{array}{r}1 \\
4 \\
7 \\
12 \\
.17\end{array}$ & $\begin{array}{r}2 \\
6 \\
12 \\
8 \\
14\end{array}$ & $\begin{array}{l}3 \\
10 \\
20^{*} \\
20 \\
31\end{array}$ & $\begin{array}{l}0 \\
0 \\
0 \\
0 \\
0\end{array}$ & $\begin{array}{l}0 \\
1 \\
0 \\
0 \\
1\end{array}$ & $\begin{array}{l}0 \\
1 \\
0 \\
0 \\
1\end{array}$ & $\begin{array}{r}1 \\
4 \\
7 \\
12 \\
17\end{array}$ & $\begin{array}{r}2 \\
7 \\
12 \\
8 \\
15\end{array}$ & $\begin{array}{c}3 \\
11 \\
20^{*} \\
20 \\
32\end{array}$ \\
\hline $\begin{array}{l}5 \ldots \ldots \ldots \ldots \ldots \\
6 \ldots \ldots \ldots \ldots \ldots \ldots \\
7 \ldots \ldots \ldots \ldots \ldots \ldots \ldots \\
8 \ldots \ldots \ldots \ldots \ldots \ldots \ldots \\
9 \ldots \ldots \ldots \ldots \ldots \ldots\end{array}$ & $\begin{array}{r}6 \\
11 \\
11 \\
9 \\
10\end{array}$ & $\begin{array}{r}8 \\
19 \\
9 \\
5 \\
8\end{array}$ & $\begin{array}{l}14 \\
30 \\
20 \\
14 \\
18\end{array}$ & $\begin{array}{l}0 \\
1 \\
0 \\
0 \\
1\end{array}$ & $\begin{array}{l}1 \\
0 \\
1 \\
0 \\
2\end{array}$ & $\begin{array}{l}1 \\
1 \\
1 \\
0 \\
3\end{array}$ & $\begin{array}{c}6 \\
12 \\
11 \\
9 \\
11\end{array}$ & $\begin{array}{r}9 \\
19 \\
10 \\
5 \\
10\end{array}$ & $\begin{array}{l}15 \\
31 \\
21 \\
14 \\
21\end{array}$ \\
\hline $\begin{array}{l}10 \ldots \ldots \ldots \\
11 \ldots \ldots \ldots \ldots \\
12 \ldots \ldots \ldots \\
13 \ldots \ldots \ldots \\
14 \ldots \ldots \ldots\end{array}$ & $\begin{array}{l}7 \\
4 \\
2 \\
4 \\
1\end{array}$ & $\begin{array}{l}8 \\
5 \\
2 \\
1 \\
6\end{array}$ & $\begin{array}{r}15 \\
9 \\
4 \\
5 \\
7\end{array}$ & $\begin{array}{l}0 \\
0 \\
0 \\
0 \\
0\end{array}$ & $\begin{array}{l}0 \\
0 \\
0 \\
0 \\
0\end{array}$ & $\begin{array}{l}0 \\
0 \\
0 \\
0 \\
0\end{array}$ & $\begin{array}{l}7 \\
4 \\
2 \\
4 \\
1\end{array}$ & $\begin{array}{l}8 \\
5 \\
2 \\
1 \\
6\end{array}$ & $\begin{array}{r}15 \\
9 \\
4 \\
5 \\
7\end{array}$ \\
\hline 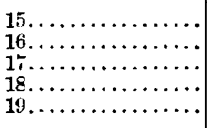 & $\begin{array}{r}2 \\
8 \\
12 \\
13 \\
12\end{array}$ & $\begin{array}{l}2 \\
0 \\
3 \\
2 \\
1\end{array}$ & $\begin{array}{r}4 \\
8 \\
15 \\
15 \\
13\end{array}$ & $\begin{array}{l}1 \\
3 \\
3 \\
5 \\
4\end{array}$ & $\begin{array}{l}0 \\
0 \\
1 \\
1 \\
0\end{array}$ & $\begin{array}{l}1 \\
3 \\
4 \\
6 \\
4\end{array}$ & $\begin{array}{l}3 \\
11 \\
15 \\
18 \\
16\end{array}$ & $\begin{array}{l}2 \\
0 \\
4 \\
3 \\
1\end{array}$ & $\begin{array}{r}5 \\
11 \\
19 \\
21 \\
17\end{array}$ \\
\hline 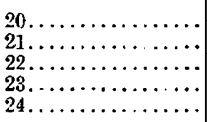 & $\begin{array}{l}15 \\
20 \\
23 \\
25 \\
23\end{array}$ & $\begin{array}{l}0 \\
3 \\
4 \\
2 \\
1\end{array}$ & $\begin{array}{l}15 \\
23 \\
27 \\
27 \\
24\end{array}$ & $\begin{array}{l}1 \\
5 \\
6 \\
8 \\
7\end{array}$ & $\begin{array}{l}0 \\
2 \\
2 \\
0 \\
0\end{array}$ & $\begin{array}{l}1 \\
7 \\
8 \\
8 \\
7\end{array}$ & $\begin{array}{l}16 \\
25 \\
29 \\
33 \\
30\end{array}$ & $\begin{array}{l}0 \\
5 \\
6 \\
2 \\
1\end{array}$ & $\begin{array}{l}16 \\
30 \\
35 \\
35 \\
31\end{array}$ \\
\hline 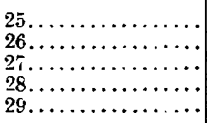 & $\begin{array}{l}31 \\
26 \\
20 \\
14 \\
20\end{array}$ & $\begin{array}{l}5 \\
3 \\
1 \\
3 \\
2\end{array}$ & $\begin{array}{l}36 \\
29 \\
21 \\
17 \\
22\end{array}$ & $\begin{array}{l}6 \\
2 \\
2 \\
2 \\
3\end{array}$ & $\begin{array}{l}1 \\
0 \\
6 \\
1 \\
0\end{array}$ & $\begin{array}{l}7 \\
2 \\
2 \\
3 \\
3 \\
3\end{array}$ & $\begin{array}{l}37 \\
28 \\
22 \\
16 \\
23\end{array}$ & $\begin{array}{l}6 \\
3 \\
1 \\
4 \\
2\end{array}$ & $\begin{array}{l}43 \\
31 \\
23 \\
20 \\
25\end{array}$ \\
\hline 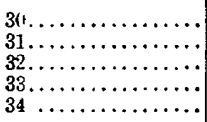 & $\begin{array}{l}22 \\
19 \\
19 \\
20 \\
22\end{array}$ & $\begin{array}{l}1 \\
1 \\
6 \\
3 \\
6\end{array}$ & $\begin{array}{l}23 \\
20 \\
25 \\
23 \\
28\end{array}$ & $\begin{array}{l}9 \\
2 \\
3 \\
3 \\
4\end{array}$ & $\begin{array}{l}1 \\
0 \\
0 \\
1 \\
0\end{array}$ & $\begin{array}{r}10 \\
2 \\
3 \\
4 \\
4\end{array}$ & $\begin{array}{l}31 \\
21 \\
22 \\
23 \\
26\end{array}$ & $\begin{array}{l}2 \\
1 \\
6 \\
4 \\
6\end{array}$ & $\begin{array}{r}33 \\
.22 \\
28 \\
27 \\
32\end{array}$ \\
\hline $\begin{array}{l}35 \ldots \ldots \ldots \\
36 \ldots \ldots \ldots \ldots \\
37 \ldots \ldots \ldots \ldots \\
38 \ldots \ldots \ldots \ldots \\
39 \ldots \ldots \ldots\end{array}$ & $\begin{array}{c}22 \\
14 \\
15 \\
9 \\
12\end{array}$ & $\begin{array}{l}4 \\
7 \\
9 \\
1 \\
2 \\
2\end{array}$ & $\begin{array}{l}26 \\
21 \\
24 \\
10 \\
14\end{array}$ & $\begin{array}{l}2 \\
4 \\
1 \\
0 \\
2\end{array}$ & $\begin{array}{l}1 \\
1 \\
1 \\
1 \\
0\end{array}$ & $\begin{array}{l}3 \\
5 \\
2 \\
1 \\
2\end{array}$ & $\begin{array}{r}24 \\
18 \\
16 \\
9 \\
14\end{array}$ & $\begin{array}{r}5 \\
8 \\
10 \\
2 \\
2\end{array}$ & $\begin{array}{l}29 \\
26 \\
26 \\
11 \\
16\end{array}$ \\
\hline 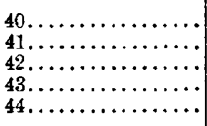 & $\begin{array}{r}14 \\
7 \\
18 \\
7 \\
12\end{array}$ & $\begin{array}{l}7 \\
3 \\
5 \\
4 \\
6\end{array}$ & $\begin{array}{l}21 \\
10 \\
23 \\
11 \\
18\end{array}$ & $\begin{array}{l}2 \\
1 \\
1 \\
0 \\
1\end{array}$ & $\begin{array}{l}0 \\
0 \\
0 \\
0 \\
0\end{array}$ & $\begin{array}{l}2 \\
1 \\
1 \\
0 \\
1\end{array}$ & $\begin{array}{r}16 \\
8 \\
19 \\
7 \\
13\end{array}$ & $\begin{array}{l}7 \\
3 \\
5 \\
4 \\
6\end{array}$ & $\begin{array}{l}23 \\
11 \\
24 \\
11 \\
19\end{array}$ \\
\hline 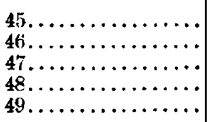 & $\begin{array}{l}6 \\
9 \\
4 \\
5 \\
5 \\
5\end{array}$ & $\begin{array}{l}4 \\
3 \\
4 \\
3 \\
5\end{array}$ & $\begin{array}{r}10 \\
12 \\
8 \\
8 \\
10\end{array}$ & $\begin{array}{l}2 \\
2 \\
0 \\
0 \\
2\end{array}$ & $\begin{array}{l}1 \\
0 \\
0 \\
1 \\
0\end{array}$ & $\begin{array}{l}3 \\
2 \\
0 \\
1 \\
2\end{array}$ & $\begin{array}{r}8 \\
11 \\
4 \\
5 \\
7\end{array}$ & $\begin{array}{l}5 \\
3 \\
4 \\
4 \\
5\end{array}$ & $\begin{array}{r}13 \\
14 \\
8 \\
9 \\
12\end{array}$ \\
\hline $\begin{array}{l}50 \ldots \ldots \ldots \ldots \ldots \ldots \\
51 \ldots \ldots \ldots \ldots \ldots \ldots \ldots \ldots \ldots \\
52 \ldots \ldots \ldots \ldots \ldots \ldots \ldots \ldots \\
53 \ldots \ldots \ldots \ldots \ldots \ldots \ldots \ldots\end{array}$ & $\begin{array}{l}7 \\
7 \\
1 \\
7 \\
4\end{array}$ & $\begin{array}{l}4 \\
4 \\
5 \\
3 \\
8\end{array}$ & $\begin{array}{l}11 \\
11 \\
6 \\
10 \\
12\end{array}$ & $\begin{array}{l}\mathbf{3} \\
\mathbf{0} \\
0 \\
\mathbf{3} \\
\mathbf{0}\end{array}$ & $\begin{array}{l}3 \\
0 \\
1 \\
0 \\
0\end{array}$ & $\begin{array}{l}6 \\
0 \\
1 \\
3 \\
0 \\
0\end{array}$ & $\begin{array}{r}10 \\
7 \\
1 \\
10 \\
4\end{array}$ & $\begin{array}{l}7 \\
4 \\
6 \\
3 \\
8\end{array}$ & $\begin{array}{r}17 \\
11 \\
7 \\
13 \\
12\end{array}$ \\
\hline 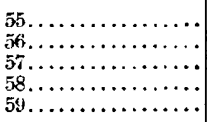 & $\begin{array}{l}4 \\
6 \\
1 \\
4 \\
3\end{array}$ & $\begin{array}{l}8 \\
4 \\
4 \\
5 \\
4\end{array}$ & $\begin{array}{r}12 \\
10 \\
5 \\
9 \\
7\end{array}$ & $\begin{array}{l}1 \\
1 \\
1 \\
0 \\
1\end{array}$ & $\begin{array}{l}0 \\
0 \\
2 \\
0 \\
0\end{array}$ & $\begin{array}{l}1 \\
1 \\
3 \\
0 \\
1\end{array}$ & $\begin{array}{l}5 \\
7 \\
2 \\
4 \\
4\end{array}$ & $\begin{array}{l}8 \\
4 \\
6 \\
5 \\
4\end{array}$ & $\begin{array}{r}13 \\
11 \\
8 \\
9 \\
8\end{array}$ \\
\hline
\end{tabular}

* Including one white child, aged 2, sex unknown. 
Table 5.-Distribution of Pellagrins According to Race, Sex and Age at Onset of First ERythema-(Continued)

\begin{tabular}{|c|c|c|c|c|c|c|c|c|c|}
\hline \multirow{2}{*}{$\begin{array}{l}\text { Age, } \\
\text { Years }\end{array}$} & \multicolumn{3}{|c|}{ White } & \multicolumn{3}{|c|}{ Colored } & \multicolumn{3}{|c|}{ Both Races } \\
\hline & Female & Male & Total & Female & Male & Total & Female & Male & Total \\
\hline $\begin{array}{l}60 \ldots \ldots \ldots \ldots \\
61 \ldots \ldots \ldots \ldots \ldots \\
62 \ldots \ldots \ldots \ldots \\
63, \ldots \ldots \ldots \ldots \\
64 \ldots \ldots \ldots \ldots \\
64 \ldots \ldots\end{array}$ & $\begin{array}{l}5 \\
? \\
2 \\
4 \\
2\end{array}$ & $\begin{array}{l}1 \\
2 \\
5 \\
2 \\
7\end{array}$ & $\begin{array}{l}6 \\
4 \\
7 \\
6 \\
9\end{array}$ & $\begin{array}{l}0 \\
0 \\
0 \\
1 \\
0\end{array}$ & $\begin{array}{l}4 \\
0 \\
0 \\
0 \\
0\end{array}$ & $\begin{array}{l}4 \\
0 \\
0 \\
1 \\
0\end{array}$ & $\begin{array}{l}5 \\
2 \\
2 \\
5 \\
2\end{array}$ & $\begin{array}{l}5 \\
2 \\
5 \\
2 \\
7\end{array}$ & $\begin{array}{r}10 \\
4 \\
7 \\
7 \\
9\end{array}$ \\
\hline 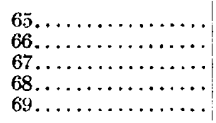 & $\begin{array}{l}3 \\
2 \\
0 \\
0 \\
1\end{array}$ & $\begin{array}{l}1 \\
0 \\
1 \\
3 \\
1\end{array}$ & $\begin{array}{l}4 \\
2 \\
1 \\
3 \\
2\end{array}$ & $\begin{array}{l}0 \\
0 \\
0 \\
2 \\
0\end{array}$ & $\begin{array}{l}0 \\
0 \\
2 \\
1 \\
0\end{array}$ & $\begin{array}{l}0 \\
0 \\
2 \\
3 \\
0\end{array}$ & $\begin{array}{l}3 \\
2 \\
0 \\
2 \\
1\end{array}$ & $\begin{array}{l}1 \\
0 \\
3 \\
4 \\
1\end{array}$ & $\begin{array}{l}4 \\
2 \\
3 \\
6 \\
2\end{array}$ \\
\hline 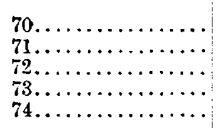 & $\begin{array}{l}2 \\
0 \\
0 \\
0 \\
0\end{array}$ & $\begin{array}{l}2 \\
0 \\
1 \\
2 \\
1\end{array}$ & $\begin{array}{l}4 \\
0 \\
1 \\
2 \\
1\end{array}$ & $\begin{array}{l}0 \\
0 \\
0 \\
0 \\
0\end{array}$ & $\begin{array}{l}0 \\
0 \\
0 \\
0 \\
0 \\
0\end{array}$ & $\begin{array}{l}0 \\
0 \\
0 \\
0 \\
0\end{array}$ & $\begin{array}{l}2 \\
0 \\
0 \\
0 \\
0\end{array}$ & $\begin{array}{l}2 \\
0 \\
1 \\
2 \\
1\end{array}$ & $\begin{array}{l}4 \\
0 \\
1 \\
2 \\
1\end{array}$ \\
\hline 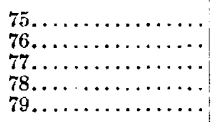 & $\begin{array}{l}0 \\
0 \\
1 \\
0 \\
0\end{array}$ & $\begin{array}{l}1 \\
0 \\
0 \\
1 \\
0\end{array}$ & $\begin{array}{l}1 \\
0 \\
1 \\
1 \\
0\end{array}$ & $\begin{array}{l}0 \\
0 \\
0 \\
0 \\
0\end{array}$ & $\begin{array}{l}0 \\
0 \\
0 \\
0 \\
0\end{array}$ & $\begin{array}{l}0 \\
0 \\
0 \\
0 \\
0\end{array}$ & $\begin{array}{l}0 \\
0 \\
1 \\
0 \\
0\end{array}$ & $\begin{array}{l}1 \\
0 \\
0 \\
1 \\
0\end{array}$ & $\begin{array}{l}1 \\
0 \\
1 \\
1 \\
0\end{array}$ \\
\hline $\begin{array}{l}80 \ldots \ldots \ldots \ldots \ldots \ldots \ldots \\
81 \ldots \ldots \ldots \ldots \ldots \ldots \ldots \ldots \ldots \\
82 \ldots \ldots \ldots \ldots \ldots \ldots \ldots \\
83 \ldots \ldots \ldots \ldots \ldots \ldots \ldots\end{array}$ & $\begin{array}{l}0 \\
0 \\
0 \\
0 \\
0\end{array}$ & $\begin{array}{l}0 \\
0 \\
1 \\
0 \\
0\end{array}$ & $\begin{array}{l}0 \\
0 \\
1 \\
0 \\
0\end{array}$ & $\begin{array}{l}0 \\
0 \\
0 \\
0 \\
0\end{array}$ & $\begin{array}{l}1 \\
0 \\
0 \\
0 \\
0\end{array}$ & $\begin{array}{l}1 \\
0 \\
0 \\
0 \\
0\end{array}$ & $\begin{array}{l}0 \\
0 \\
0 \\
0 \\
0\end{array}$ & $\begin{array}{l}1 \\
0 \\
1 \\
0 \\
0\end{array}$ & $\begin{array}{l}1 \\
0 \\
1 \\
0 \\
0\end{array}$ \\
\hline $\begin{array}{l}85 \ldots \ldots \ldots \ldots \ldots \ldots \ldots \\
86 \ldots \ldots \ldots \ldots \ldots \ldots \ldots \ldots \\
87 \ldots \ldots \ldots \ldots \ldots \ldots \ldots \ldots \\
89 \ldots \ldots \ldots \ldots \ldots \ldots \ldots\end{array}$ & $\begin{array}{l}0 \\
0 \\
0 \\
0 \\
0\end{array}$ & $\begin{array}{l}0 \\
0 \\
0 \\
0 \\
0\end{array}$ & $\begin{array}{l}0 \\
0 \\
0 \\
0 \\
0\end{array}$ & $\begin{array}{l}1 \\
0 \\
0 \\
0 \\
0\end{array}$ & $\begin{array}{l}0 \\
0 \\
0 \\
0 \\
0\end{array}$ & $\begin{array}{l}1 \\
0 \\
0 \\
0 \\
0\end{array}$ & $\begin{array}{l}1 \\
0 \\
0 \\
0 \\
0\end{array}$ & $\begin{array}{l}0 \\
0 \\
0 \\
0 \\
0\end{array}$ & $\begin{array}{l}1 \\
0 \\
0 \\
0 \\
0\end{array}$ \\
\hline Total, age known & 699 & 310 & $1,010^{*}$ & 115 & 36 & 151 & 814 & 346 & $1,161^{*}$ \\
\hline Age unknown..... & 13 & 4 & 17 & 2 & $\mathbf{0}$ & 2 & 15 & 4 & 19 \\
\hline Total ........... & 712 & 314 & $1,027^{*}$ & 117 & 36 & 153 & 829 & 350 & $1,180^{*}$ \\
\hline
\end{tabular}

* Including one white child, aged 2, sex unknown.

according to age at the time of onset, of the total 1,180 pellagrins is shown graphically in Figure 2; of the 712 white females in Figure 3; of the 314 white males in Figure 4, and of the 117 colored females and thirty-six colored males in Figure 5.

One important point brought out here is the occurrence of fourteen initial attacks of pellagra before the age of two years, three of them in the first year of life and eleven in the second. These fourteen cases amount to more than 1 per cent. of the total 1,180 cases, a proportion somewhat greater than that shown in the previous study ${ }^{5}$ of 253 pellagrins according to age at onset of the disease, in which series there were only two individuals under the age of two years.

5. Siler, Garrison and MacNeal: The Archives Int. Med., 1915, xv, 106; Second Progress Report, 1915, 121. 


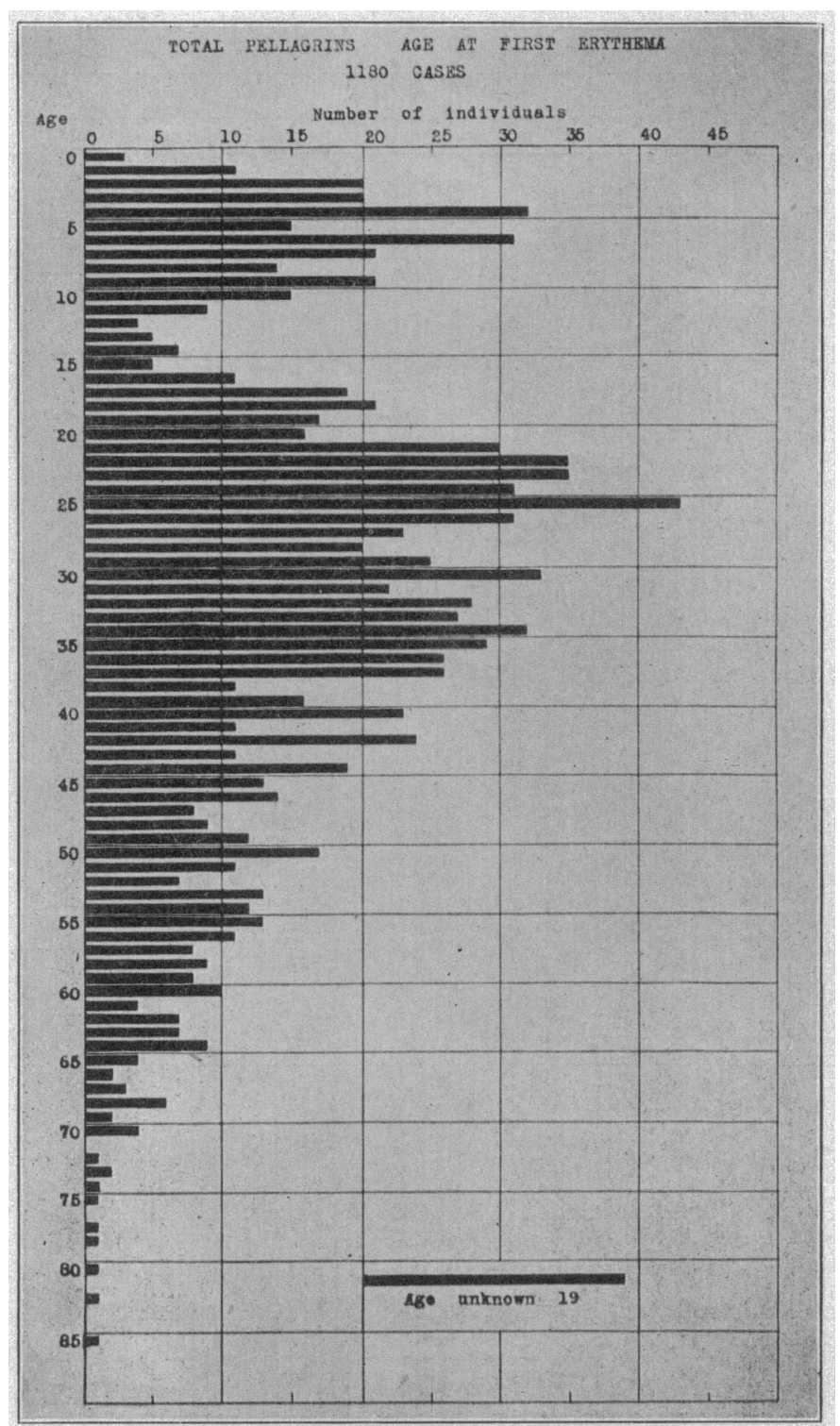

Fig. 2.-The distribution, according to age in years at the onset of the initial erythema, is shown for 1,161 pellagrins. In nineteen cases the age at onset could not be ascertained. One white child, aged 2, whose sex was not recorded, is also included here. 


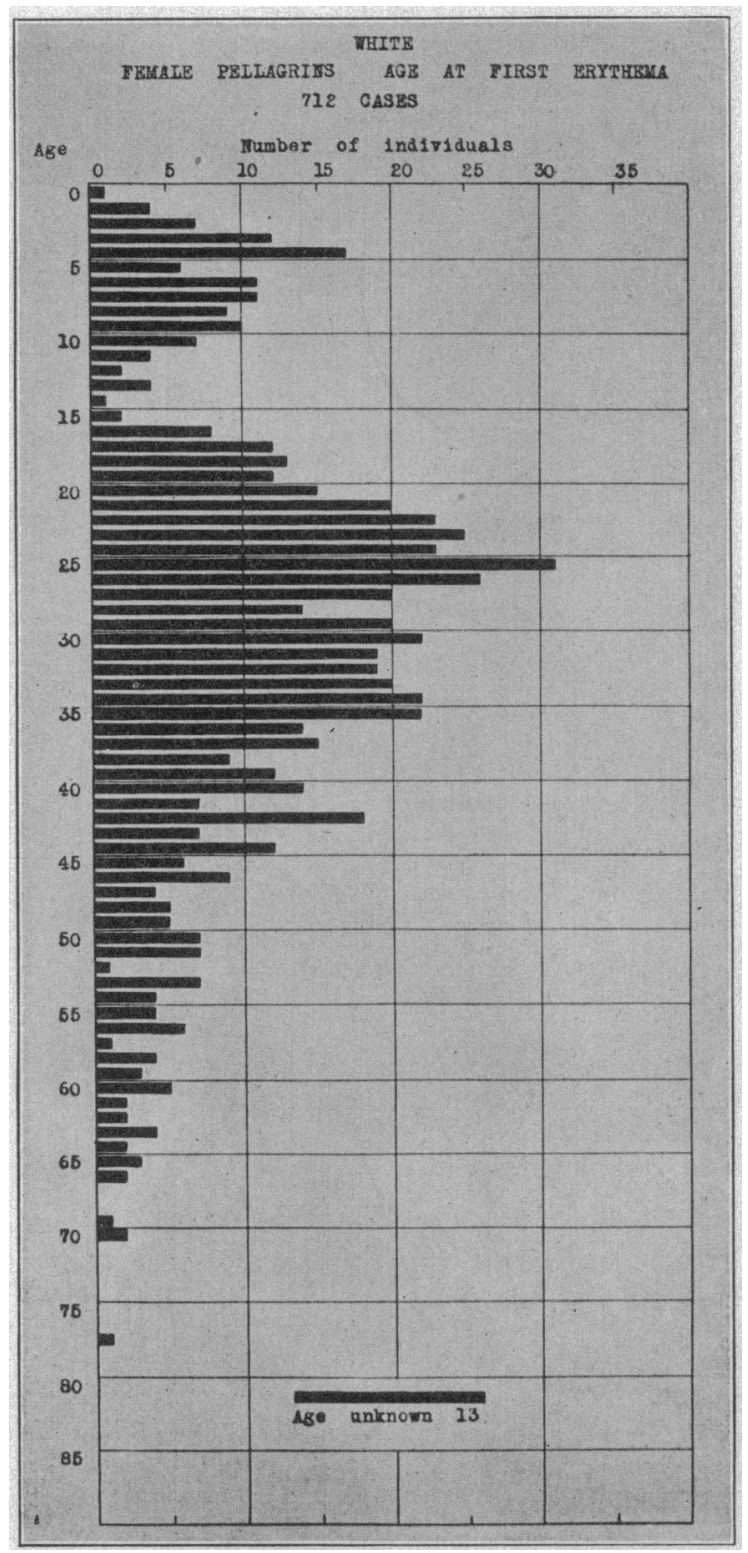

Fig. 3.-The distribution, according to age in years at the onset of the initial erythema, is shown for 699 white female pellagrins. In thirteen cases the age at onset could not be ascertained. 


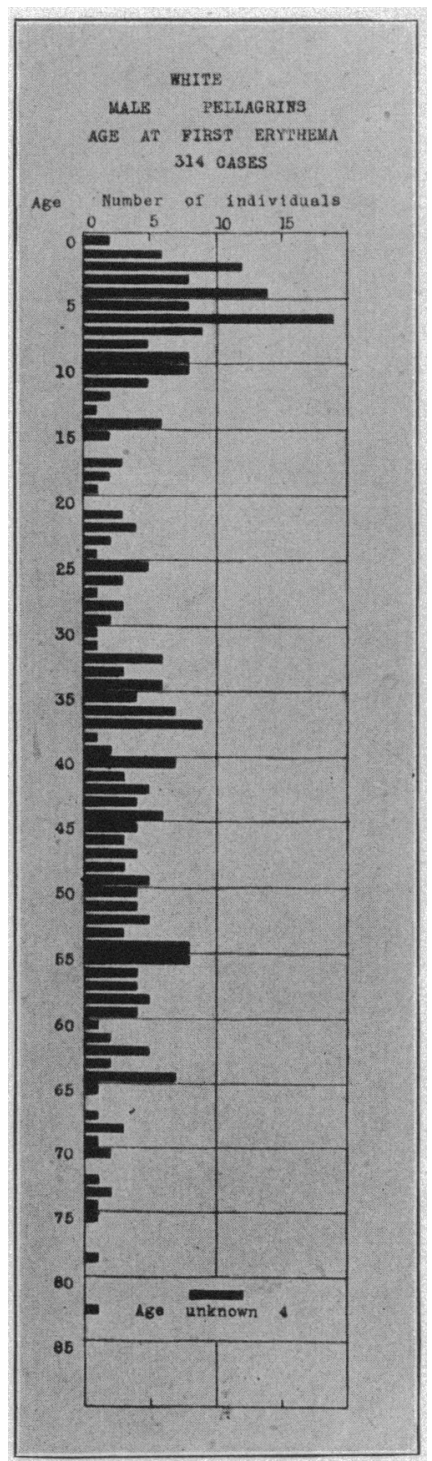

Fig. 4.-The distribution, according to age in years at the onset of the initial erythema, is shown for 310 white male pellagrins. In four cases the age at onset could not be ascertained. 


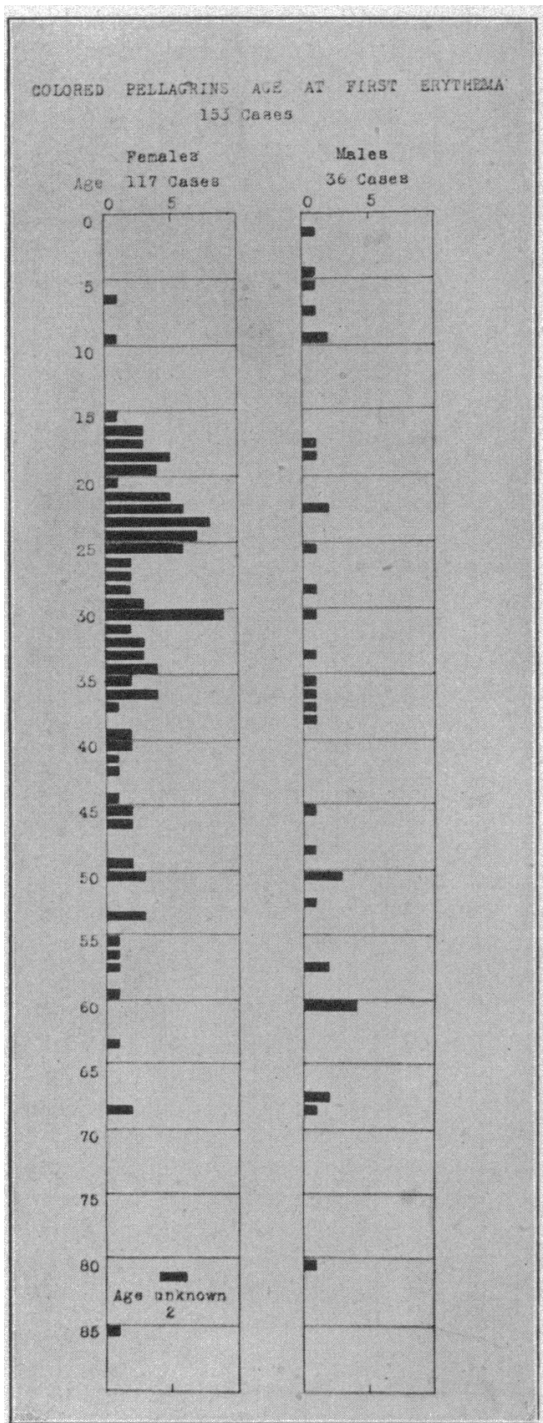

Fig. 5.-The distribution, according to age in years at the onset of the initial erythema, is shown for 115 colored female pellagrins and thirty-six colored male pellagrins. In two of the colored female pellagrins the age at onset could not be ascertained. 
These fourteen cases, which originated before the age of two years, are perhaps worthy of a detailed consideration.

Pellagrin 120: I. L., girl, was born in October, 1909. The initial attack of pellagra began June 1, 1911, at the age of 19 months, with recovery. She had measles in January, 1912, and died of dysentery after a week's illness in April, 1912. Whether this dysentery was or was not a manifestation of pellagra is uncertain. There was no pellagra in any other member of the family. An adult pellagrin, No. 353, residing next door, suffered a severe recurrent attack of pellagra, lasting all summer, in 1911, and died of it in November, 1911. An unrelated woman, Pellagrin 678, living in the same house with the child, Pellagrin 120, suffered an initial attack of pellagra at about the same time as the child. This case, Pellagrin 120, was reported to us by Dr. A. W. Nelson of Spartanburg and was not seen by any member of our commission.

Pellagrin 173: A. J., boy, was born in March, 1910. The onset of the initial erythema occurred in June, 1911, at the age of 15 months. The case was seen and diagnosed by Dr. J. W. Babcock of Columbia, S. C. There were no recurrences in 1912, 1913 or 1914. This boy's mother, Pellagrin 171, had her initial attack of pellagra in October, 1910, six months after the child's birth, and she had a recurrent attack in April, 1911, two months before the onset of the erythema in the child. These attacks of pellagra were not seen by any member of our commission.

Pellagrin 179: R. L. R., boy, was born June 10, 1910. The initial erythema began in February, 1912, at the age of 20 months, on the backs of the hands and wrists, and it was accompanied by diarrhea. The erythema appeared on the feet in June and this was still desquamating when the patient was seen by us Aug. 23, 1912. The erythema recurred on hands and feet in 1913 and again in 1914 and the little boy died in July, 1914. The older sister of this child, Pellagrin 310, is said by the parents to have had the same disease when she died in August, 1910, at the age of 4 years. A paternal aunt, Pellagrin 170, living in the same house, developed pellagra for the first time in June, 1911, and had a severe recurrence in 1912. In February, 1911, this child, Pellagrin 179 , with his parents, moved to another house, next door but one to the former residence, and it was at this new residence that the symptoms of pellagra appeared, in February, 1912.

Pellagrin 184: W. B., colored boy, was born March 4, 1911. The initial attack of pellagra began with erythema and dysentery on June 7, 1912, at the age of 15 months, and terminated in death July 6, 1912. The child had been weaned on May 25, only a short time before the onset of pellagra, but he had been eating an indiscriminate diet since the age of 5 months. The child's mother, Pellagrin 183, developed her initial attack of pellagra June 1, 1912, a few days before the onset of the erythema in his case. A paternal aunt of the child, Pellagrin 67, visited this family during May and June of 1912, and the onset of her cutaneous eruption occurred at their home on May 22, 1912. The disease appeared in her sister-in-law, Pellagrin 183, and nephew, Pellagrin 184, in less than three weeks after the appearance of the erythema in their guest. This child was seen by Dr. J. C. Moore of Duncan, S. C., who made the diagnosis, and the family was interviewed by us in August, 1912, six weeks after the child's death.

Pellagrin 643: L. O. A., girl, was born Aug. 23, 1907. The initial attack of pellagra began in July, 1909, at the age of 22 months, and the disease recurred in the summer of 1910 . There was no recurrence in $1911,1912,1913$ or 1914. The case originated in an endemic focus of pellagra outside of Spartanburg County and moved into this county at a later date. There were no other known pellagrins in the family. The diagnosis of this infantile case rests entirely upon the history.

Pellagrin 645: F. S., boy, was born Sept. 24, 1909. The onset of pellagra occurred, according to the mother, in March, 1910, at the age of 6 months. 
The disease recurred in the summer of 1911 and again in 1912, but there was no recurrence in 1913 or 1914 . His mother, Pellagrin 644, had her initial attack of pellagra in April, 1909, five months before his birth, and she had mild recurrences in 1910, 1911, 1912 and 1913, but no recurrence in 1914. Her mother, the maternal grandmother of Pellagrin 645 , is also a pellagrin, Case 83 , with onset in 1910. This family was first seen by us in 1913 and the diagnosis of infantile pellagra rests entirely upon the history.

Pellagrin 672: B. D., boy, was born in the spring or summer of 1910. The onset of pellagra occurred in the summer of 1911, at the approximate age of 1 year. There was no recurrence in 1912, 1913 or 1914 . The boy's paternal grandfather, Pellagrin 131, lived in the same household. He had suffered his first attack of pellagra in 1910 and had a severe recurrence early in the spring of 1911, preceding the onset of the disease in the child. The child's father, mother and sister have not shown any signs of the disease. This case occurred before the beginning of our field work and the diagnosis of infantile pellagra rests entirely upon the history.

Pellagrin 888: F. E., boy, was born Aug. 18, 1908. The onset of pellagra occurred, according to the parents, in March, 1909, at the. approximate age of 6 months. The disease recurred each spring, 1910, 1911, 1912, 1913 and 1914. There are no other known pellagrins in the family and only a history of visiting at the house of a pellagrin during early infancy. This case came under our observation for the first time in 1914. The patient was seen, however, by Dr. J. J. Allen of Enoree, S. C., in the spring of 1909, and he states that pellagra actually was present at the age of 6 months, evidenced by characteristic erythema of the hands and feet and well-marked gastro-intestinal symptoms.

Pellagrin 1010: D. T., boy, was born Oct. 3, 1912. The initial attack of pellagra began in June, 1914, at the age of 20 months. There were no other known pellagrins in the family. This boy contracted the disease while living in an endemic focus in a neighboring county and came under our observation when the family moved to Spartanburg in June, 1914. The attack of pellagra was very definite and the eruption quite typical. It was still present at our last recorded observation, Aug. 12, 1914.

Pellagrin 941 : C. L. C., girl, was born June 23, 1912. Her initial pellagrous erythema began May 1, 1914, at the age of 22 months. She was seen by tis on June 14, 1914, when a typical erythema of the backs of the hands was still present. A maternal uncle, Pellagrin 449, came to make his home with this family in August, 1912. He had had an attack of pellagra in 1912 and possibly also in 1911 . There was a severe recurrence in March, 1913, and again in May, 1914, resulting in death at the Pellagra Hospital on May 30, 1914. Another maternal uncle of this baby, Pellagrin 856 , who had been suffering from gastro-intestinal trouble for three years and had been adjudged insane in 1912, came on a visit to this family in May, 1913. A pellagrous erythema appeared upon his hands early in June, 1913. He left again in July and died of pellagra in North Carolina, Aug. 14, 1913. He probably had had the diagnostic erythema in previous years, but the evidence on this point is not conclusive. The baby's mother, Pellagrin 450, showed her first definite erythema in March or April, 1913, with recovery, and there was no recurrence in 1914. The baby slept with her uncle, Pellagrin 449, up to the time he was taken to the hospital.

Pellagrin 1026: T. L., girl, was born in November, 1912. The initial erythena appeared July 23, 1914, at the age of 20 months. The child's father, Pellagrin 529, developed his initial attack of pellagra on March 17, 1913, at a village about ten miles from Spartanburg. The attack was severe and, as he was unable to support his wife and child, all three were taken into the home of the wife's parents, who, although not in comfortable circumstances, were nevertheless somewhat above the average of mill workers in financial status. Six weeks later, on May 17, 1913, the wife's father, Pellagrin 530, came down with a severe initial attack of pellagra, from which he died on July 16. 
1913, at the Pellagra Hospital, four days after admission. At about the same time, his wife, Pellagrin 1228, developed a mild erythema from which she soon recovered. A son of the old man lived just across the street and his wife, who was assisting in her father-in-law's household during this time of sickness, also developed her initial attack of pellagra about May 15, 1913, which proved to be mild in character. The original patient, Pellagrin 529 (patient's father), was sent away to the mountains of Tennessee on June 15, 1913, and he died there shortly afterward. The old lady, Pellagrin 1228, died early in 1914. without recurrence. The baby, Pellagrin 1026, showed her initial erythema in July, 1914, and was evidently recovering when seen by us on Aug. 6, 1914. No other members of the family had shown any evidence of pellagra up to that time.

Pellagrin 1133: W. B., boy, was born in 1911. The initial attack occurred in the spring of 1912 at the approximate age of 1 year, according to the history. The disease recurred in 1913 and there was a severe recurrence again in the early spring of 1914, with good recovery. This patient was seen by us for the first time in September, 1914, at which time there were, of course, no recognizable signs of pellagra.

Pellagrin 1164: O. M. D., boy, was born Dec. 27, 1912. The pellagrous erythema appeared on the hands, forearms, feet and legs in June, 1914, at the age of 18 months, but it was preceded by a persistent gastro-intestinal disorder, manifested by vomiting and diarrhea, which began March 30 . Evidence of very typical desquamation was still present when seen by us Sept. 30 . 1914. There were no other recognized cases of pellagra in the household. The family lived on a farm and the nearest known pellagrin was an aunt of the baby, Pellagrin 29, living two miles away, who suffered her first attack in 1910, with recurrences each year. A history of association with this aunt was not obtainable.

Pellagrin 1220: A. R. P., girl, was born Sept. 5, 1913. The onset of pellagra occurred in August, 1914, at the age of 11 months, with erythema on backs of hands, which later extended up the arms to the shoulders. When seen on October 3 , there was still some desquamation on the arms and shoulders and the condition was considered to be pellagra, although an absolutely positive diagnosis could not be made from the appearance at that time. The child was still nursing its mother, but had also been taking solid food, chiefly wheat bread and sweet potato, for several months. The child's father, Pellagrin 1134 , had his first attack of pellagra in June, 1913, about three months before the birth of the child and he suffered a recurrent attack in the summer of 1914. The mother of this child and a brother, aged 4, have shown no signs of pellagra.

The data in regard to these fourteen cases are briefly summarizel in Table 6.

Certain characteristics of pellagra in early life are illustrated by these cases. In the first place, there are here only two examples of pellagra as early as the seventh month. Neither of these two patients was seen by us until some years after the onset of pellagra and in onc case, Pellagrin 645, we have no authority for the diagnosis at this early age except the statements of members of the family. The subsequent history makes it very certain that the patient actually suffered from pellagra, but does not make certain the time of onset. The other case, Pellagrin 888, seems to be better established as an actual instance of onset at age of 6 months. During our field investigations we made a special search for infantile cases of pellagra and neglected no opportunity to see them. Most of the infantile cases reported to us proved 
disappointing upon closer examination. We feel very certain therefore that definitely recognizable cases of pellagra in children under the age of 12 months have been extremely rare in Spartanburg County.

Another feature of interest is the evidence of very intimate association or the presence of an antecedent case of pellagra in the household where the infant has contracted the disease. In three instances, Pellagrins 173, 645 and 941, the mother had been a pellagrin for several months before the child developed the disease; in one instance the mother came down with pellagra at about the same time as the child, Pellagrin 184 . In this latter case the disease was evidently introduced into the household by a paternal aunt visiting there. In another

Table 6.-The Fourteen Pellagrins in Whom the Disease Appeared Before, THE AgE OF 2 YeARS

\begin{tabular}{|c|c|c|c|c|c|}
\hline $\begin{array}{l}\text { Pella- } \\
\text { grin } \\
\text { No. }\end{array}$ & Born & $\begin{array}{c}\text { Onset } \\
\text { of } \\
\text { Pellagra }\end{array}$ & $\begin{array}{l}\text { Age at } \\
\text { Onset, } \\
\text { Mos. }\end{array}$ & Recurrences & $\begin{array}{c}\text { Authority } \\
\text { for } \\
\text { Diagnosis }\end{array}$ \\
\hline 645 & Sept. 1909 & Mar. 1910 & 6 & 1912,1913 & History only \\
\hline 888 & Aug. 1908 & Mar. 1909 & 6 & $\begin{array}{c}1910,1911,1912, \\
1913,1914\end{array}$ & \\
\hline 1,220 & Sept. 1913 & Aug. 1914 & 11 & ................... & Seen, Oct. 3, 1914 \\
\hline 672 & 1910 & 1911 & $12(?)$ & None & History only \\
\hline 1.133 & 1911 & Spring 1912 & $12(?)$ & 1913,1914 & History only \\
\hline 173 & Mar. 1910 & June 1911 & 15 & None & Dr. J. W. Babock \\
\hline 184 & Mar. 1911 & June 1912 & 15 & Death, 1912 & Dr. J. C. Moore \\
\hline 1,164 & Dec. 1912 & June 1914 & 18 & .............. & Seen \\
\hline 120 & Oet. 1909 & June 1911 & 19 & Death, 1912 & Dr. A. W. Nelson \\
\hline 179 & June 1910 & Feb. 1912 & 20 & 1913, 1914, D. & Seen \\
\hline 1,010 & Oet. 1912 & July 1914 & 20 & . & Seen \\
\hline 1,026 & Nov. 1912 & July 1914 & 20 & . & Seen \\
\hline 941 & June 1912 & May 1914 & 22 & & Seen \\
\hline 643 & Aug. 1907 & July 1909 & 22 & 1910 & History only \\
\hline
\end{tabular}

instance, Pellagrin 672, the paternal grandfather was the earlier case in the household; in two instances, Pellagrins 1,026 and 1,220, the child's father seems to have brought pellagra into the family. In one instance, Pellagrin 179, the earliest known case in the family was a sister, aged 4 years. Following this, the disease appeared in an aunt living in the same house, and after separation from this aunt the disease appeared in the young child, Pellagrin 179. In one instance, Pellagrin 120, the child developed pellagra simultaneously with an unrelated woman living in the same house, the nearest antecedent case being next door. In five instances, Pellagrins 643, 888, 1,010, 1,133 and 1,164 there were no other known pellagrins in the household. Three of these 
cases $(643,888$ and 1,133$)$ arose previous to the beginning of our field work and their environments at the time could not be investigated. A fourth case, Pellagrin 1,010, originated in a neighboring county and the family moved into Spartanburg County on July 20,1914, left the baby in the hospital and disappeared without giving us opportunity to obtain the desired information and about three weeks later the child was removed from the hospital by an aunt, who left no address. The fifth case, Pellagrin 1,164, originated in an isolated farm house, the nearest known pellagrin being an aunt two miles away, with whom there was no evident association. This series of cases in young children, therefore, furnishes more definite evidence of the dependence of incident pellagra upon close association with a preexisting case of the disease than is ordinarily found in the study of the disease as it originates in adults. This more clear-cut picture might be expected because of the relatively limited social intercourse of children under two years of age. It seems probable also that the incubation period of the disease is shorter and less variable in these young children than in older persons, which may also tend to simplify the problem.

It is interesting to note that in only four instances was the mother known to have pellagra and in only one instance, Pellagrin 645, did she have the disease previous to the birth of the child. When we bear in mind the relatively enormous prevalence of pellagra among childbearing women in the endemic areas, it would seem remarkable that the simultaneous occurrence of pellagra in mother and infant child should be rare. A pellagrous father, grandfather, aunt or unrelated visitor in the household, considering the relative frequency of such association, seems to be as significant as the presence of a pellagrous mother. Child-bearing women make up a very large proportion of the cases of pellagra in Spartanburg County and an acute attack of pellagra is very frequently seen during the puerperium. The fact that young infants so rarely have pellagra and that only three children under the age of two years contracted the disease subsequent to its appearance in their mothers seems highly significant and indicates that the milk of pellagrous women cannot be regarded as an important agency in causing pellagra, either in the rôle of a vehicle of the hypothetical specific infectious or toxic causative agent or as a food deficient in elements, to the lack of which pellagra may be ascribed. Indeed one occasionally sees a happy, fat and healthy infant, whose only food has come from the breast of a pellagrous mother lying on her death-bed, and even if not well nourished and happy, it is nevertheless the rule for the children of pellagrous women to remain free from any sign of pellagra during infancy and especially during the period of exclusive breast-feeding. To those who are familiar with infantile beriberi and 
its enormous prevalence and death rate in the Philippine Islands, ${ }^{6}$ the contrast between infantile pellagra and infantile beriberi will be sufficiently striking.

Of the fourteen cases, only one died in the initial attack of pellagra and this one was the only negro child in the group. All white children survived the year of onset. One of them, Pellagrin 184, died the following April of acute dysentery, without recurrence of skin lesions. Another, Pellagrin 179, survived the initial attack and a recurrence the following year and died in the third summer after the disease had recurred. The remaining eleven children were alive at our last observation of them.

In the age period between 2 and 12 years there were 198 instances of onset of pellagra. Their distribution according to race, sex and age at onset is shown graphically in Figures 2, 3, 4 and 5 and the data are printed, along with the data for the fourteen younger children, in Table 7. It will be noted that 212 of the total 1,180 recorded cases, or nearly 18 per cent., had their onset before the age of 12 years. This is important when we recall how little attention has been paid, relatively, to pellagra in children living in their own homes. Of the 212 children, 204 were white and eight were colored, a ratio of 25.5 to 1 , indicating that pellagra in this county has been relatively much more rare in negro children than in adult negroes. This is in accord with the hypothesis previously suggested, that pellagra has not as yet established itself as an endemic disease among the negroes of this county

6. The age distribution of deaths from beriberi in Manila, according to the government reports compiled from data in Quarterly Report of Bureau of Health of the Philippine Islands is as shown in the following tabulation:

\begin{tabular}{|c|c|c|c|c|c|c|c|c|c|}
\hline \multirow{2}{*}{ Age } & \multicolumn{3}{|c|}{1912} & \multicolumn{3}{|c|}{1913} & \multicolumn{3}{|c|}{1914} \\
\hline & Female & Male & Total & Female & Male & Total & Femaie & Male & Total \\
\hline Under $1 \ldots$. & 397 & 490 & 887 & 317 & 370 & 687 & 389 & 510 & 899 \\
\hline 1 to $4 \ldots \ldots \ldots$ & 29 & 27 & 56 & 7 & 13 & 20 & 20 & 8 & 28 \\
\hline 5 to $9 \ldots$ & 2 & 2 & 4 & 7 & 4 & 11 & 2 & 4 & 6 \\
\hline 10 to $14 \ldots$ & 5 & 3 & 8 & 1. & 3 & 4 & 1 & 1 & 2 \\
\hline 15 to $19 \ldots$ & 3 & 16 & 19 & 3 & 8 & 11 & 5 & 11 & 16 \\
\hline 20 to $29 . .$. & 7 & 11 & 18 & 10 & 6 & 16 & 13 & 6 & 19 \\
\hline 30 to $39 \ldots$ & 10 & 16 & 26 & 12 & 13 & 25 & 14 & 17 & 31 \\
\hline 40 to $49 \ldots$. & 4 & 26 & 30 & 5 & 27 & 32 & 3 & 17 & 20 \\
\hline Over $50 \ldots \ldots \ldots$ & 14 & 28 & 42 & 10 & 12 & 22 & 6 & 15 & 21 \\
\hline Total......... & 471 & 619 & 1.090 & 372 & 456 & $8 \varepsilon 8$ & 453 & 589 & 1,042 \\
\hline
\end{tabular}


to the same degree as in the white race. The negro children, being the most completely segregated portion of their race, are relativly least afflicted with pellagra.

In the whole group of 212 children there were seven deaths in the year of the initial attack: three in white girls, age at onset being 4,8 and 10 years; two in white boys, age at onset being 3 and 11 years; two in colored boys, age at onset being 1 and 5 years, respectively. 'The indicated death rate in first attack for children under 12 years is therefore quite low, 2.5 per cent. for white children, 25 per cent. for colored children and 3.3 per cent. for all the children considered together. The group of pellagrins originating in the age period from 2 to 12 years is of peculiar interest because of the large number of cases and the low mortality in the year of onset.

table 7.-Pellagrins with Onset at Age Below 12 Years, Distributed According to Race, Sex and Age at Onset of the Initial Erythema

\begin{tabular}{l|r|r|r|r|r|r|r|r|r|r|r|r|r}
\hline & \multicolumn{10}{c|}{ Age in Years } \\
\hline & 0 & 1 & 2 & 3 & 4 & 5 & 6 & 7 & 8 & 9 & 10 & 11 & Total \\
\hline White girls..... & 1 & 4 & 7 & 12 & 17 & 6 & 11 & 11 & 9 & 10 & 7 & 4 & 99 \\
White boys.... & 2 & 6 & 12 & 8 & 14 & 8 & 19 & 9 & 5 & 8 & 8 & 5 & 104 \\
Colored girls... & 0 & 0 & 0 & 0 & 0 & 0 & 1 & 0 & 0 & 1 & 0 & 0 & 2 \\
Colored boys... & 0 & 1 & 0 & 0 & 1 & 1 & 0 & 1 & 0 & 2 & 0 & 0 & 6 \\
\hline Total........ & 3 & 11 & $20^{*}$ & 20 & 32 & 15 & 31 & 21 & 14 & 21 & 15 & 0 & $212^{*}$ \\
\hline
\end{tabular}

* Including one white child, aged 2, of unknown sex.

The age period from 12 to 16 years shows only twenty-one initial attacks of pellagra, nine in white girls, eleven in white boys and one in a colored girl aged 15 . Of the twenty-one incident cases, only one died in the year of onset, Pellagrin 475, a white girl, aged 13. The low incidence of pellagra in these four years is in marked contrast to the incidence in younger persons of both sexes and to that in older women.

Up to the age of 16 , the difference between boys and girls has been slight, although one may see indication of a greater tendency for boys to get pellagra under the age of 3 . The greatest contrast on the other hand is shown between the white race and the colored race. Of the whole group of 233 incident cases under 16 years of age, 224 were white and only nine were colored persons, a ratio of 25 to 1 . Taken in connection with the undoubtedly inferior food of the negroes in this county, as regards quality, quantity and variety, together with the 
equally certain greater relative segregation of the negro children from association with pellagrins, these facts seem highly significant for the problem of the etiology of pellagra and may not be without value in considering the prevention of the disease. After the age of 16 the sex distinction in pellagra incidence becomes very prominent, but the racial relationships are not without interest. The distribution of the incident cases in the four years from age 16 to age 20 is shown in 'Table 8. The remarkable difference in sex incidence of pellagra in this population, namely the great excess of female pellagrins over male pellagrins, has been pointed out in our previous reports. Here it is strikingly shown that this difference becomes manifest at about the seventeenth year of life and the change from the relative equality of the earlier years is a sharp one.

Table 8.-Pellagrins with Initial Atrack Between Ages 16 and 20, Distributed According to Race, Sex and Age at Onset

\begin{tabular}{|c|c|c|c|c|c|}
\hline & \multicolumn{5}{|c|}{ Age in Years } \\
\hline & 16 & 17 & 18 & 19 & Total \\
\hline White women...... & 8 & 12 & 13 & 12 & 45 \\
\hline White men. & 0 & 3 & 2 & 1 & 6 \\
\hline Colored women.............. & 3 & 3 & 5 & 4 & 15 \\
\hline Colored men......... & 0 & 1 & 1 & 0 & 2 \\
\hline Total women... & 10 & 16 & 18 & 16 & 60 \\
\hline Total men..................... & 0 & 4 & 3 & 1 & 8 \\
\hline Grand total................ & 10 & 20 & 21 & 17 & 68 \\
\hline
\end{tabular}

Another remarkable feature of the table is the relatively high incidence in colored women, fifteen colored women and forty-five white women, a ratio of 1 to 3 . Previous to the age 16 , in the data considered above, there were three colored girls, one of them 15 years old, and 108 white girls, the ratio being 1 to 36 . The enormous rise in pellagra incidence in negro women in the age period from 16 to 20 years is not only very great as compared with younger negroes, but it is relatively enormous in comparison even with the large increase in incidence in white women which takes place at this time. Among the possible explanations for this greater increase in pellagra incidence in adolescent colored women, may be mentioned the somewhat earlier and somewhat more sudden change to the adult state in the negro race. This may play some part. Another possible factor, which seems to us of great importance, is the closer association with the white race which 
the negro women experience at about this time. Many of them are engaged in domestic service or as day nurses to care for children. In many instances childbearing begins before the age of twenty, and this may also play a part. It has been impossible to get reliable histories in most of these cases of colored women, and it seems not worth while to go into details in regard to them. In only a few cases was there evidence of close association with antecedent cases of pellagra and in only three instances were there earlier cases of pellagra in the household. In three other instances a history of domestic service, such as cooking and washing clothes for mill-village people, was obtained. One patient gave birth to an illegitimate child in the year following the onset of pellagra.

The deaths during the year of initial attack for the age period 16 to 20 years are shown in Table 9 . The characteristic racial difference in death rate is again evident here.

TABle 9.-Death Rate from Pellagra During the Year of Initial Attack in the Age Period 16 to 20 Years

\begin{tabular}{|c|c|c|c|c|c|c|c|c|c|}
\hline & \multicolumn{3}{|c|}{ White } & \multicolumn{3}{|c|}{ Colored } & \multicolumn{3}{|c|}{ Both Races } \\
\hline & Women & Men & Total & Women & Men & Total & Women & Men & Total \\
\hline Initial attacks.......... & 45 & 6 & 51 & 15 & 2 & 17 & 60 & 8 & 68 \\
\hline Deaths in initial attack. & 3 & 0 & 3 & 7 & 1 & 8 & 10 & 1 & 11 \\
\hline Mortality per cent. & 6.7 & 0.0 & 5.9 & 46.7 & 50.0 & 47.1 & 16.7 & 12.5 & 16.2 \\
\hline
\end{tabular}

From the age of 20 years to that of 50 years the women show a very much higher incidence of pellagra than the men, the disparity being greater in the earlier years and gradually approaching equality at age 50. The number of initial attacks in each five-year period after age 20 is shown in Table 10. The number of female pellagrins is enormously greater than the number of male pellagrins in the third decade of life, but in the later age periods the number of women attacked diminishes rapidly while the number of men increases somewhat, and after age 55 years the female pellagrins are actually less numerous than the male.

The death rate in year of initial attack for each race and sex, by decades after age 20 , is shown in Table 11. For the women the figures are large enough to indicate a consistent increase in the death rate in initial attack correlated with increased age at onset, ranging from 4.6 per cent. in the third decade to 47.6 per cent. in the seventh decade. For the other three groups the number of cases is somewhat small and deductions correspondingly less reliable. The death rate 
J. F. SILER-P. E. GARRISON-W. J. M'NEAL

Table 10.-Initial Atracks of Pellagra in Each Race and Sex by Frve-Year Periods After Age 20

\begin{tabular}{|c|c|c|c|c|c|c|c|c|c|}
\hline \multirow{2}{*}{ Age } & \multicolumn{3}{|c|}{ White } & \multicolumn{3}{|c|}{ Colored } & \multicolumn{3}{|c|}{ Both Races } \\
\hline & Women & Men & Total & Women & Men & Total & Women & Men & Total \\
\hline 20 to $24 \ldots \ldots \ldots \ldots$ & 106 & 10 & 116 & 27 & 4 & 31 & 133 & 14 & 147 \\
\hline 25 to $29 \ldots \ldots$ & 111 & 14 & 125 & 15 & 2 & 17 & I26 & 16 & 142 \\
\hline 30 to $34 \ldots$. & 102 & 17 & 119 & 21 & 2 & 23 & 123 & 19 & 142 \\
\hline 35 to $39 . .$. & 72 & 23 & 95 & 9 & 4 & 13 & 81 & 27 & 108 \\
\hline 40 to $44 \ldots$ & 58 & 25 & 83 & 5 & 0 & 5 & 63 & 25 & 88 \\
\hline 45 to $49 \ldots$. & 29 & 19 & 48 & 6 & 2 & 8 & 35 & 21 & 56 \\
\hline 50 to $54 \ldots$ & 26 & 24 & 50 & 6 & 4 & 10 & 32 & 28 & 60 \\
\hline 55 to $59 \ldots \ldots$ & 18 & $2 \overline{5}$ & 43 & 4 & 2 & 6 & 22 & 27 & 49 \\
\hline 60 to $64 \ldots \ldots$ & 15 & 17 & 32 & 1 & 4 & 5 & 16 & 21 & 37 \\
\hline 65 to $69 . .$. & 6 & 6 & 12 & 2 & 3 & 5 & 8 & 9 & 17 \\
\hline 70 to $74 \ldots \ldots$ & 2 & 6 & 8 & 0 & 0 & 0 & 2 & 6 & 8 \\
\hline 75 to $79 \ldots \ldots$ & 1 & 2 & 3 & 0 & 0 & 0 & 1 & 2 & 3 \\
\hline 80 to $84 \ldots .$. & 0 & 1 & 1. & 0 & 1 & 1 & 0 & 2 & 2 \\
\hline 85 to $89 . \ldots \ldots \ldots \ldots$ & 0 & 0 & 0 & 1 & 0 & 1 & 1 & 0 & 1 \\
\hline
\end{tabular}

TABLE 11.-Deaths in Year of Onset of Pellagra for Each Race and Sex, According to Age by Decades After Age 20

\begin{tabular}{|c|c|c|c|c|c|c|c|c|}
\hline & \multicolumn{8}{|c|}{ Decades } \\
\hline & 20 to 29 & 30 to 39 & 40 to 49 & 50 to 59 & 60 to 69 & 70 to 79 & 80 to 89 & Total \\
\hline $\begin{array}{l}\text { White Women } \\
\text { Inftial attacks.. }\end{array}$ & 217 & 174 & 87 & 44 & 21 & 3 & 0 & 546 \\
\hline Deaths........... & 10 & 17 & 13 & 14 & 10 & 1 & 0 & 65 \\
\hline Rate, per cent. .. & 4.6 & 9.8 & 14.9 & 31.8 & 47.6 & 32.3 & $\cdots \cdots$ & 11.9 \\
\hline $\begin{array}{l}\text { White Men } \\
\text { Initial attacks.. }\end{array}$ & 24 & 40 & 44 & 49 & 23 & 8 & 1 & 189 \\
\hline Deatbs........... & 4 & 8 & 7 & 12 & 5 & 3 & 1 & 40 \\
\hline Rate, per cent. .. & \pm 6.7 & 20.0 & 15.9 & 24.5 & 21.7 & 37.5 & 100.0 & 21.2 \\
\hline $\begin{array}{l}\text { Colored Women } \\
\text { Initial attacks.. }\end{array}$ & 42 & 30 & 11 & 10 & 3 & 0 & 1 & 97 \\
\hline Deaths........... & 13 & 13 & 7 & 4 & 2 & 0 & 0 & 39 \\
\hline Rate, per cent. .. & 31.0 & 43.3 & 63.6 & 40.0 & 66.7 & $\cdots \cdots$ & 0.0 & 40.2 \\
\hline $\begin{array}{l}\text { Colored Men } \\
\text { Inftial attacks.. }\end{array}$ & 6 & 6 & 2 & 6 & 7 & 0 & 1 & 28 \\
\hline Deaths........... & 2 & 3 & 0 & 3 & 5 & 0 & 1 & 14 \\
\hline Rate, per cent. .. & 33.3 & 50.0 & 0.0 & 50.0 & 71.4 & $\ldots \ldots$ & 100.0 & 50.0 \\
\hline
\end{tabular}


Table 12.-Distribution, According to Race, Sex and Age at Onset of Initial Erythema, of the 187 Pelcagrins Who Died in the Year of the Initial Attack

\begin{tabular}{|c|c|c|c|c|c|c|c|c|c|}
\hline \multirow{2}{*}{ Age } & \multicolumn{3}{|c|}{ White } & \multicolumn{3}{|c|}{ Colored } & \multicolumn{3}{|c|}{ Both Races } \\
\hline & Female & Male & Total & Female & Male & Total & Female & Male & Total \\
\hline 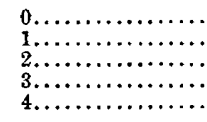 & $\begin{array}{l}0 \\
0 \\
0 \\
0 \\
1\end{array}$ & $\begin{array}{l}0 \\
0 \\
0 \\
1 \\
0\end{array}$ & $\begin{array}{l}0 \\
0 \\
0 \\
1 \\
1\end{array}$ & $\begin{array}{l}0 \\
0 \\
0 \\
0 \\
0 \\
0\end{array}$ & $\begin{array}{l}0 \\
1 \\
0 \\
0 \\
0\end{array}$ & $\begin{array}{l}0 \\
1 \\
0 \\
0 \\
0\end{array}$ & $\begin{array}{l}0 \\
0 \\
0 \\
0 \\
0 \\
1\end{array}$ & $\begin{array}{l}0 \\
1 \\
0 \\
1 \\
0\end{array}$ & $\begin{array}{l}0 \\
1 \\
0 \\
1 \\
1\end{array}$ \\
\hline 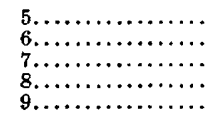 & $\begin{array}{l}0 \\
0 \\
0 \\
1 \\
0\end{array}$ & $\begin{array}{l}0 \\
0 \\
0 \\
0 \\
0\end{array}$ & $\begin{array}{l}0 \\
0 \\
0 \\
1 \\
0\end{array}$ & $\begin{array}{l}0 \\
0 \\
0 \\
0 \\
0 \\
0\end{array}$ & $\begin{array}{l}1 \\
0 \\
0 \\
0 \\
0\end{array}$ & $\begin{array}{l}1 \\
0 \\
0 \\
0 \\
0\end{array}$ & $\begin{array}{l}0 \\
0 \\
0 \\
1 \\
0\end{array}$ & $\begin{array}{l}1 \\
0 \\
0 \\
0 \\
0\end{array}$ & $\begin{array}{l}1 \\
0 \\
0 \\
1 \\
0\end{array}$ \\
\hline 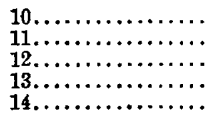 & $\begin{array}{l}1 \\
0 \\
0 \\
1 \\
0\end{array}$ & $\begin{array}{l}0 \\
0 \\
1 \\
0 \\
0\end{array}$ & $\begin{array}{l}1 \\
0 \\
1 \\
1 \\
0\end{array}$ & $\begin{array}{l}0 \\
0 \\
0 \\
0 \\
0\end{array}$ & $\begin{array}{l}0 \\
0 \\
0 \\
0 \\
0\end{array}$ & $\begin{array}{l}0 \\
0 \\
0 \\
0 \\
0\end{array}$ & $\begin{array}{l}1 \\
0 \\
0 \\
1 \\
0\end{array}$ & $\begin{array}{l}0 \\
0 \\
1 \\
0 \\
0\end{array}$ & $\begin{array}{l}1 \\
0 \\
1 \\
1 \\
0\end{array}$ \\
\hline 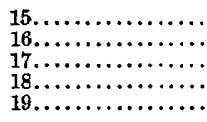 & $\begin{array}{l}0 \\
1 \\
0 \\
1 \\
1\end{array}$ & $\begin{array}{l}0 \\
0 \\
0 \\
0 \\
0\end{array}$ & $\begin{array}{l}0 \\
1 \\
0 \\
1 \\
1\end{array}$ & $\begin{array}{l}0 \\
2 \\
1 \\
3 \\
1\end{array}$ & $\begin{array}{l}0 \\
0 \\
0 \\
1 \\
0\end{array}$ & $\begin{array}{l}0 \\
2 \\
1 \\
4 \\
1\end{array}$ & $\begin{array}{l}0 \\
3 \\
1 \\
4 \\
2\end{array}$ & $\begin{array}{l}0 \\
0 \\
0 \\
1 \\
0\end{array}$ & $\begin{array}{l}0 \\
3 \\
1 \\
5 \\
2\end{array}$ \\
\hline 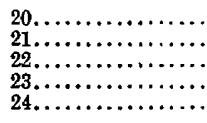 & $\begin{array}{l}0 \\
3 \\
0 \\
0 \\
0 \\
2\end{array}$ & $\begin{array}{l}0 \\
1 \\
1 \\
0 \\
1\end{array}$ & $\begin{array}{l}0 \\
4 \\
1 \\
0 \\
3\end{array}$ & $\begin{array}{l}0 \\
0 \\
1 \\
4 \\
3\end{array}$ & $\begin{array}{l}0 \\
0 \\
1 \\
0 \\
0\end{array}$ & $\begin{array}{l}0 \\
0 \\
2 \\
4 \\
3\end{array}$ & $\begin{array}{l}0 \\
3 \\
1 \\
4 \\
5 \\
5\end{array}$ & $\begin{array}{l}0 \\
1 \\
2 \\
0 \\
1\end{array}$ & $\begin{array}{l}0 \\
4 \\
3 \\
4 \\
6\end{array}$ \\
\hline 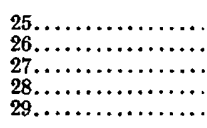 & $\begin{array}{l}2 \\
0 \\
1 \\
0 \\
2\end{array}$ & $\begin{array}{l}1 \\
0 \\
0 \\
0 \\
0\end{array}$ & $\begin{array}{l}3 \\
0 \\
1 \\
0 \\
2\end{array}$ & $\begin{array}{l}4 \\
1 \\
0 \\
0 \\
0\end{array}$ & $\begin{array}{l}0 \\
0 \\
0 \\
1 \\
0\end{array}$ & $\begin{array}{l}4 \\
1 \\
0 \\
1 \\
0\end{array}$ & $\begin{array}{l}6 \\
1 \\
1 \\
0 \\
2\end{array}$ & $\begin{array}{l}1 \\
0 \\
0 \\
1 \\
0\end{array}$ & $\begin{array}{l}7 \\
1 \\
1 \\
1 \\
2\end{array}$ \\
\hline 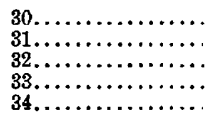 & $\begin{array}{l}1 \\
1 \\
1 \\
3 \\
3\end{array}$ & $\begin{array}{l}0 \\
0 \\
1 \\
0 \\
2\end{array}$ & $\begin{array}{l}1 \\
1 \\
2 \\
3 \\
5\end{array}$ & $\begin{array}{l}4 \\
0 \\
1 \\
1 \\
1\end{array}$ & $\begin{array}{l}1 \\
0 \\
0 \\
0 \\
0\end{array}$ & $\begin{array}{l}5 \\
0 \\
1 \\
1 \\
1\end{array}$ & $\begin{array}{l}5 \\
1 \\
2 \\
4 \\
4 \\
4\end{array}$ & $\begin{array}{l}1 \\
0 \\
1 \\
0 \\
2\end{array}$ & $\begin{array}{l}6 \\
1 \\
3 \\
4 \\
6\end{array}$ \\
\hline 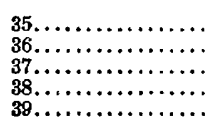 & $\begin{array}{l}2 \\
2 \\
2 \\
1 \\
1\end{array}$ & $\begin{array}{l}2 \\
1 \\
1 \\
0 \\
1\end{array}$ & $\begin{array}{l}4 \\
3 \\
3 \\
1 \\
2 \\
2\end{array}$ & $\begin{array}{l}1 \\
4 \\
0 \\
0 \\
1\end{array}$ & $\begin{array}{l}1 \\
0 \\
0 \\
1 \\
0\end{array}$ & $\begin{array}{l}2 \\
4 \\
n \\
1 \\
1\end{array}$ & $\begin{array}{l}3 \\
6 \\
2 \\
1 \\
2\end{array}$ & $\begin{array}{l}3 \\
1 \\
1 \\
1 \\
1\end{array}$ & $\begin{array}{l}6 \\
7 \\
3 \\
2 \\
3\end{array}$ \\
\hline 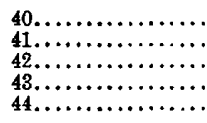 & $\begin{array}{l}5 \\
1 \\
2 \\
1 \\
0\end{array}$ & $\begin{array}{l}3 \\
0 \\
1 \\
0 \\
0\end{array}$ & $\begin{array}{l}8 \\
1 \\
3 \\
1 \\
0\end{array}$ & $\begin{array}{l}2 \\
0 \\
0 \\
0 \\
1\end{array}$ & $\begin{array}{l}0 \\
0 \\
0 \\
0 \\
0\end{array}$ & $\begin{array}{l}2 \\
0 \\
0 \\
0 \\
1\end{array}$ & $\begin{array}{l}7 \\
1 \\
2 \\
1 \\
1\end{array}$ & $\begin{array}{l}3 \\
0 \\
1 \\
0 \\
0\end{array}$ & $\begin{array}{r}10 \\
1 \\
3 \\
1 \\
1\end{array}$ \\
\hline 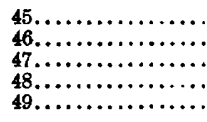 & $\begin{array}{l}0 \\
3 \\
1 \\
0 \\
0\end{array}$ & $\begin{array}{l}2 \\
1 \\
0 \\
0 \\
0\end{array}$ & $\begin{array}{l}2 \\
4 \\
1 \\
0 \\
0\end{array}$ & $\begin{array}{l}1 \\
2 \\
0 \\
0 \\
1\end{array}$ & $\begin{array}{l}0 \\
0 \\
0 \\
0 \\
0\end{array}$ & $\begin{array}{l}1 \\
2 \\
0 \\
0 \\
1\end{array}$ & $\begin{array}{l}1 \\
5 \\
1 \\
0 \\
1\end{array}$ & $\begin{array}{l}2 \\
1 \\
0 \\
0 \\
0\end{array}$ & $\begin{array}{l}3 \\
6 \\
1 \\
0 \\
1\end{array}$ \\
\hline 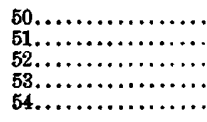 & $\begin{array}{l}2 \\
0 \\
2 \\
1 \\
1\end{array}$ & $\begin{array}{l}3 \\
0 \\
3 \\
1 \\
2\end{array}$ & $\begin{array}{l}5 \\
0 \\
5 \\
2 \\
3\end{array}$ & $\begin{array}{l}2 \\
0 \\
0 \\
1 \\
0\end{array}$ & $\begin{array}{l}2 \\
0 \\
1 \\
0 \\
0\end{array}$ & $\begin{array}{l}4 \\
0 \\
1 \\
1 \\
0\end{array}$ & $\begin{array}{l}4 \\
0 \\
2 \\
2 \\
1\end{array}$ & $\begin{array}{l}5 \\
0 \\
4 \\
1 \\
2\end{array}$ & $\begin{array}{l}9 \\
0 \\
6 \\
3 \\
3 \\
3\end{array}$ \\
\hline 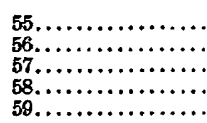 & $\begin{array}{l}2 \\
2 \\
\mathbf{0} \\
3 \\
1\end{array}$ & $\begin{array}{l}1 \\
1 \\
1 \\
0 \\
0\end{array}$ & $\begin{array}{l}3 \\
3 \\
1 \\
1 \\
3 \\
1\end{array}$ & $\begin{array}{l}1 \\
0 \\
0 \\
0 \\
0\end{array}$ & $\begin{array}{l}0 \\
0 \\
0 \\
0 \\
0\end{array}$ & $\begin{array}{l}1 \\
0 \\
0 \\
0 \\
0\end{array}$ & $\begin{array}{l}3 \\
2 \\
0 \\
3 \\
1 \\
1\end{array}$ & $\begin{array}{l}1 \\
1 \\
1 \\
0 \\
0\end{array}$ & $\begin{array}{l}4 \\
3 \\
1 \\
3 \\
1\end{array}$ \\
\hline
\end{tabular}


Table 12.-Distribution, According to Race, Sex and Age at Onset of Initial Erythema, of the 187 Pellagrins Who Died in the Year of the Initial AtTack-(Continued)

\begin{tabular}{|c|c|c|c|c|c|c|c|c|c|}
\hline \multirow{2}{*}{ Age } & \multicolumn{3}{|c|}{ White } & \multicolumn{3}{|c|}{ Colored } & \multicolumn{3}{|c|}{ Both Races } \\
\hline & Female & Male & Total & Female & Male & Total & Female & Male & Total \\
\hline 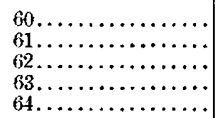 & $\begin{array}{l}3 \\
2 \\
0 \\
2 \\
0\end{array}$ & $\begin{array}{l}0 \\
0 \\
1 \\
1 \\
2\end{array}$ & $\begin{array}{l}3 \\
2 \\
1 \\
3 \\
2\end{array}$ & $\begin{array}{l}0 \\
0 \\
0 \\
0 \\
0\end{array}$ & $\begin{array}{l}3 \\
0 \\
0 \\
0 \\
0\end{array}$ & $\begin{array}{l}3 \\
0 \\
0 \\
0 \\
0\end{array}$ & $\begin{array}{l}3 \\
2 \\
0 \\
2 \\
0\end{array}$ & $\begin{array}{l}3 \\
0 \\
1 \\
1 \\
2\end{array}$ & $\begin{array}{l}6 \\
2 \\
1 \\
\mathbf{1} \\
3 \\
2\end{array}$ \\
\hline 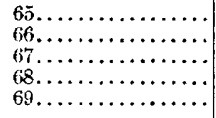 & $\begin{array}{l}2 \\
1 \\
0 \\
0 \\
0\end{array}$ & $\begin{array}{l}0 \\
0 \\
1 \\
0 \\
0\end{array}$ & $\begin{array}{l}2 \\
1 \\
1 \\
0 \\
0\end{array}$ & $\begin{array}{l}0 \\
0 \\
0 \\
2 \\
0\end{array}$ & $\begin{array}{l}0 \\
0 \\
1 \\
1 \\
0\end{array}$ & $\begin{array}{l}0 \\
0 \\
1 \\
3 \\
0\end{array}$ & $\begin{array}{l}2 \\
1 \\
0 \\
2 \\
0\end{array}$ & $\begin{array}{l}0 \\
0 \\
2 \\
1 \\
0\end{array}$ & $\begin{array}{l}2 \\
1 \\
2 \\
3 \\
0\end{array}$ \\
\hline 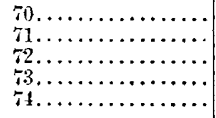 & $\begin{array}{l}1 \\
0 \\
0 \\
0 \\
0\end{array}$ & $\begin{array}{l}2 \\
0 \\
0 \\
0 \\
0 \\
0\end{array}$ & $\begin{array}{l}3 \\
0 \\
0 \\
0 \\
0\end{array}$ & $\begin{array}{l}0 \\
0 \\
0 \\
0 \\
0\end{array}$ & $\begin{array}{l}0 \\
0 \\
0 \\
0 \\
0\end{array}$ & $\begin{array}{l}0 \\
0 \\
0 \\
0 \\
0\end{array}$ & $\begin{array}{l}1 \\
0 \\
0 \\
0 \\
0\end{array}$ & $\begin{array}{l}2 \\
0 \\
0 \\
0 \\
0\end{array}$ & $\begin{array}{l}3 \\
0 \\
0 \\
0 \\
0\end{array}$ \\
\hline 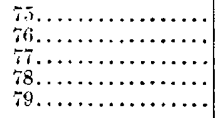 & $\begin{array}{l}0 \\
0 \\
0 \\
0 \\
0\end{array}$ & $\begin{array}{l}1 \\
0 \\
0 \\
0 \\
0\end{array}$ & $\begin{array}{l}1 \\
0 \\
0 \\
0 \\
0\end{array}$ & $\begin{array}{l}0 \\
0 \\
0 \\
0 \\
0\end{array}$ & $\begin{array}{l}0 \\
0 \\
0 \\
0 \\
0\end{array}$ & $\begin{array}{l}0 \\
0 \\
0 \\
0 \\
0\end{array}$ & $\begin{array}{l}0 \\
0 \\
0 \\
0 \\
0\end{array}$ & $\begin{array}{l}1 \\
0 \\
0 \\
0 \\
0\end{array}$ & $\begin{array}{l}1 \\
0 \\
0 \\
0 \\
0\end{array}$ \\
\hline 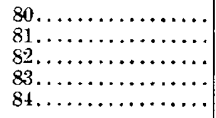 & $\begin{array}{l}\mathbf{0} \\
0 \\
0 \\
0 \\
0\end{array}$ & $\begin{array}{l}0 \\
0 \\
1 \\
0 \\
0\end{array}$ & $\begin{array}{l}0 \\
0 \\
1 \\
0 \\
0\end{array}$ & $\begin{array}{l}0 \\
0 \\
0 \\
0 \\
0\end{array}$ & $\begin{array}{l}1 \\
0 \\
0 \\
0 \\
0\end{array}$ & $\begin{array}{l}1 \\
0 \\
0 \\
0 \\
0\end{array}$ & $\begin{array}{l}0 \\
0 \\
0 \\
0 \\
0\end{array}$ & $\begin{array}{l}1 \\
0 \\
1 \\
0 \\
0\end{array}$ & $\begin{array}{l}1 \\
0 \\
1 \\
0 \\
0\end{array}$ \\
\hline Total, age known. & 72 & 42 & 114 & 46 & 17 & 63 & 118 & 59 & 177 \\
\hline Age unknown...... & 6 & 3 & 9 & 1 & 0 & 1 & 7 & 3 & 10 \\
\hline Total........... & 78 & 45 & 123 & 47 & 17 & 64 & 125 & 62 & 187 \\
\hline
\end{tabular}

in first attack seems to be more uniform for the white men, but there is some increase toward old age and the death rate of the whole group is nearly twice as high as for the white women. In the negroes over 20 years of age the death rate in first attack is nearly 50 per cent., somewhat higher for men than women and somewhat higher in the later decades of life. The number of cases available here is small, especially in the group of colored men.

In Table 12 are presented the detailed data in regard to race, sex and age at onset of pellagra of all the 187 patients who died in the year of the initial attack.

\section{AGE DISTRIBUTION OF PELLAGRINS INCIDENT IN EACH YEAR}

The distribution according to race, sex and age at onset, by five-year periods, of the incident cases of pellagra in each year after 1907 and for all those with onset previous to 1908, is shown in detail in Table 13. The data of these tables, although summarized into five-year 
TABle 13.-The Distribution of Initial Attacks of Pellagra in Different Years, According to Race, Sex and Age at Time

of Onser, by Five-Year Age Periods

\begin{tabular}{|c|c|c|c|c|c|c|c|c|c|}
\hline \multirow{2}{*}{ Age } & \multicolumn{3}{|c|}{ White } & \multicolumn{3}{|c|}{ Colored } & \multicolumn{3}{|c|}{ Both Races } \\
\hline & Female & Male & Total & Female & Male & Total & Female & Male & Total \\
\hline Before 1908 & & & & & & & & & \\
\hline 0 to 4 & 1 & 0 & 1 & 0 & 0 & 0 & 1 & 0 & 1 \\
\hline 5 to 9 & 0 & 0 & 0 & 0 & 0 & 0 & 0 & 0 & 0 \\
\hline 10 to 14 & 0 & 0 & 0 & 0 & 0 & 0 & 0 & 0 & 0 \\
\hline 15 to 19 & 3 & 0 & 3 & 2 & 0 & 2 & 5 & 0 & 5 \\
\hline 20 to 24 & 10 & 0 & 10 & 0 & 0 & 0 & 10 & 0 & 10 \\
\hline 25 to 29 & 2 & 0 & 2 & 0 & 0 & 0 & 2 & 0 & 2 \\
\hline 30 to 34 & 5 & 1 & 6 & 1 & 1 & 2 & 6 & 2 & 8 \\
\hline 35 to 39 & 5 & 1 & 6 & 1 & 0 & 1 & 6 & 1 & 7 \\
\hline 40 to 44 & 4 & 3 & 7 & 0 & 0 & 0 & 4 & 3 & 7 \\
\hline $4 \overline{5}$ to 49 & 4 & 1 & 5 & 0 & 0 & 0 & 4 & 1 & 5 \\
\hline 50 to 54 & 3 & 1 & 4 & 1 & 0 & 1 & 4 & 1 & 5 \\
\hline 55 to 59 & 2 & 3 & 5 & 0 & 0 & 0 & 2 & 3 & 5 \\
\hline 60 to 64 & 0 & 2 & 2 & 0 & 0 & 0 & 0 & 2 & 2 \\
\hline 65 to 69 & 0 & 0 & 0 & 0 & 0 & 13 & 0 & 0 & 0 \\
\hline Over 70 & 0 & 0 & 0 & 0 & 0 & 0 & 0 & 0 & 0 \\
\hline Age unknown & 0 & 0 & 0 & 0 & 0 & 0 & 0 & 0 & 0 \\
\hline Total..... & 39 & 12 & 51 & 5 & 1 & 6 & 44 & 13 & 57 \\
\hline 1908 & & & & & & & & & \\
\hline 0 to 4 & 0 & 0 & 0 & 0 & 0 & 0 & $\mathbf{0}$ & 0 & 0 \\
\hline 5 to 9 & 1 & 1 & 2 & 0 & 0 & 0 & 1 & 1 & 2 \\
\hline 10 to 14 & 0 & 0 & 0 & 0 & 0 & 0 & 0 & 0 & 0 \\
\hline 15 to 19 & 1 & 0 & 1 & 0 & 0 & 0 & 1 & 0 & 1 \\
\hline 20 to 24 & 6 & 0 & 6 & 0 & 0 & 0 & 6 & 0 & 6 \\
\hline 25 to 29 & 5 & 0 & 5 & 0 & 0 & 0 & 5 & 0 & 5 \\
\hline 30 to 34 & 3 & 0 & 3 & 0 & 0 & 0 & 3 & 0 & 3 \\
\hline 35 to 39 & 0 & 0 & 0 & 0 & 0 & 0 & 0 & 0 & 0 \\
\hline 40 to 44 & 0 & 1 & 1 & 0 & 0 & 0 & 0 & $\mathbf{1}$ & 1 \\
\hline $4 \overline{5}$ to $4 \%$ & 1 & 0 & 1 & 0 & 0 & 0 & 1 & 0 & 1 \\
\hline 50 to 54 & 0 & 0 & 0 & 0 & 0 & 0 & 0 & 0 & 0 \\
\hline 55 to 59 & 0 & 0 & 0 & 0 & 0 & 0 & 0 & 0 & 0 \\
\hline 60 to 64 & 0 & 0 & 0 & 0 & 0 & 0 & 0 & 0 & 0 \\
\hline 65 to 69 & 0 & 0 & 0 & 0 & 0 & 0 & 0 & 0 & 0 \\
\hline Age unknown & 1 & 0 & 1 & 9 & 0 & 0 & 1 & 0 & 1 \\
\hline Total........ & 18 & 2 & 20 & 0 & 0 & 0 & 18 & 2 & 20 \\
\hline
\end{tabular}


TABle 13.-The Distribution of Initial Attacks of Pellagra in Different Years, According to Race, Sex and Age at Time of Onset, by Five-Year Age Periods-(Continued)

\begin{tabular}{|c|c|c|c|c|c|c|c|c|c|}
\hline \multirow{2}{*}{ Age } & \multicolumn{3}{|c|}{ White } & \multicolumn{3}{|c|}{ Colored } & \multicolumn{3}{|c|}{ Both Races } \\
\hline & Female & Male & Totál & Female & Male & Total & Female & Male & Total \\
\hline 1909 & & & & & & & & & \\
\hline 0 to 4 & 1 & 1 & 2 & 0 & 0 & 0 & 1 & 1 & 2 \\
\hline 5 to 9 & 0 & 0 & 0 & 0 & 0 & 0 & 0 & 0 & 0 \\
\hline 10 to 14 & 0 & 0 & 0 & 0 & 0 & 0 & 0 & 0 & 0 \\
\hline 15 to 19 & 1 & 0 & 1 & 2 & 0 & 2 & 3 & 0 & 3 \\
\hline 20 to 24 & 9 & 0 & 9 & 0 & 0 & 0 & 9 & 0 & 9 \\
\hline 25 to 29 & 7 & 0 & 7 & 0 & 0 & 0 & 7 & 0 & 7 \\
\hline 30 to 34 & 5 & 0 & 5 & 0 & 0 & 0 & 5 & 0 & 5 \\
\hline 35 to 39 & 5 & 1 & 6 & 0 & 0 & 0 & 5 & 1 & 6 \\
\hline 40 to 44 & 1 & 2 & 3 & 0 & 0 & 0 & 1 & 2 & 3 \\
\hline 45 to 49 & 1 & 2 & 3 & 0 & 0 & 0 & 1 & 2 & 3 \\
\hline 50 to 54 & 3 & 4 & 7 & 1 & 0 & 1 & 4 & 4 & 8 \\
\hline 55 to 59 & 3 & 2 & 5 & 0 & 0 & 0 & 3 & 2 & 5 \\
\hline 60 to 64 & 1 & 1 & 2 & 0 & 0 & 0 & 1 & 1 & 2 \\
\hline 65 to 69 & 0 & 2 & 2 & 0 & 1 & 1 & 0 & 3 & 3 \\
\hline Over 70 & 0 & 0 & 0 & 0 & 0 & 0 & 0 & 0 & 0 \\
\hline Age unknown & 0 & 1 & 1 & 0 & 0 & 0 & 0 & 1 & 1 \\
\hline Total..... & 37 & 16 & 53 & 3 & 1 & 4 & 40 & 17 & 57 \\
\hline 1910 & & & & & & & & & \\
\hline 0 to 4 & 2 & 2 & 4 & 0 & 0 & 0 & 2 & 2 & 4 \\
\hline 5 to 9 & 3 & 3 & 6 & 1 & 1 & 2 & 4 & 4 & 8 \\
\hline 10 to 14 & 0 & 1 & 1 & 0 & 0 & 0 & 0 & 1 & 1 \\
\hline 15 to 19 & 11 & 1 & 12 & 2 & 0 & 2 & 13 & 1 & 14 \\
\hline 20 to 24 & 9 & 1 & 10 & 5 & 2 & 7 & 14 & 3 & 17 \\
\hline 25 to 29 & 19 & 1 & 20 & 2 & 8 & 2 & 21 & 1 & 22 \\
\hline 30 to 34 & 14 & 2 & 16 & 1 & 0 & 1 & 15 & 2 & 17 \\
\hline 35 to 39 & 5 & 3 & 8 & 1 & 0 & 1 & 6 & 3 & 9 \\
\hline 40 to 44 & 8 & 1 & 9 & 0 & 0 & 0 & 8 & 1 & 9 \\
\hline 45 to 49 & 4 & 1 & 5 & 1 & 0 & I & 5 & 1 & 6 \\
\hline 50 to 54 & 6 & 4 & 10 & 0 & 0 & 0 & 6 & 4 & 10 \\
\hline 55 to 59 & 3 & 3 & 6 & : & 0 & 1 & 4 & 3 & 7 \\
\hline 60 to 64 & 3 & 4 & 7 & 0 & 0 & 0 & 3 & 4 & 7 \\
\hline 65 to 69 & 2 & 0 & 2 & 1 & 0 & 1 & 3 & 0 & 3 \\
\hline Over 70 & I & 2 & 3 & 0 & 0 & 0 & 1 & 2 & $\mathbf{3}$ \\
\hline Age unknown & 3 & 1 & 4 & 0 & 0 & 0 & 3 & 1 & 4 \\
\hline Total.. & 93 & 30 & 123 & 15 & 3 & 18 & 108 & 33 & 141 \\
\hline
\end{tabular}


Table 13.-The Distribution of Initial Attacks of Pellagra in Different Years, According to Race, Sex and Age at Time of Onset, by Five-Year Age Periods-(Continued)

\begin{tabular}{|c|c|c|c|c|c|c|c|c|c|}
\hline \multirow{2}{*}{ Age } & \multicolumn{3}{|c|}{ White } & \multicolumn{3}{|c|}{ Colored } & \multicolumn{3}{|c|}{ Both Races } \\
\hline & Female & Male & Total & Female & Male & Total & Female & Male & Total \\
\hline 1911 & & & & & & & & & \\
\hline 0 to 4 & 5 & 12 & $18^{*}$ & 0 & 0 & 0 & 5 & 12 & $18^{*}$ \\
\hline 5 to 9 & 5 & 5 & 10 & 0 & 1 & 1 & 5 & 6 & 11 \\
\hline 30 to 14 & 2 & 8 & 10 & 0 & 0 & 0 & 2 & 8 & 10 \\
\hline 15 to 10 & 11 & 3 & 14 & 1 & 1 & 2 & 12 & 4 & 16 \\
\hline 20 to 24 & 20 & 1 & 21 & 3 & 0 & 3 & 23 & 1 & 24 \\
\hline 25 to 29 & 24 & 3 & 27 & 5 & 0 & 5 & 22 & 3 & 32 \\
\hline 30 to 34 & 21 & 2 & 23 & 4 & 1 & 5 & 25 & 3 & 28 \\
\hline 35 to 39 & 16 & 6 & 22 & 1 & 0 & 1 & 17 & 6 & 23 \\
\hline 40 to 44 & 17 & 6 & 23 & 0 & 0 & 0 & 17 & 8 & 23 \\
\hline 45 to 49 & 6 & 5 & 11 & 0 & 1 & 1 & 6 & 6 & 12 \\
\hline 50 to 54 & 3 & 4 & 7 & 2 & 0 & 2 & 5 & 4 & 9 \\
\hline 55 to 59 & 3 & 8 & 11 & 2 & 0 & 2 & 5 & 8 & 13 \\
\hline 60 to 64 & 2 & 2 & 4 & 0 & 1 & 1 & 2 & 3 & 5 \\
\hline 65 to 69 & 2 & 0 & 2 & 0 & o & 0 & 2 & 0 & 2 \\
\hline Over 70 & 0 & 3 & 3 & 0 & 1 & 1 & 0 & 4 & 4 \\
\hline Age unknown & 3 & 0 & $s$ & 1 & 0 & 1 & 4 & 0 & 4 \\
\hline Total.......... & 140 & 68 & 209* & 19 & 6 & 25 & 159 & 74 & $234^{*}$ \\
\hline 1912 & & & & & & & & & \\
\hline 0 to 4 & 9 & 7 & 16 & $\mathbf{0}$ & 1 & 1 & 9 & 8 & 17 \\
\hline 5 to 9 & 11 & 14 & 25 & 1 & 0 & 1 & 12 & 14 & 26 \\
\hline 10 to 14 & 7 & 3 & 10 & 0 & 0 & 0 & 7 & 3 & 10 \\
\hline 15 to 19 & 10 & 1 & 11 & 3 & 0 & 3 & 13 & 1 & 14 \\
\hline 20 to 24 & 11 & 3 & 14 & 8 & 1 & 9 & 19 & 4 & 23 \\
\hline 25 to 29 & 14 & 4 & 18 & 1 & 0 & 1 & 15 & 4 & 19 \\
\hline 30 to 34 & 15 & 6 & 21 & 6 & 0 & 6 & 21 & 6 & 27 \\
\hline 35 to 39 & 17 & 2 & 19 & 0 & 0 & 0 & 17 & 2 & 18 \\
\hline 40 to 44 & 9 & 8 & 17 & 1 & 0 & 1 & 10 & 8 & 18 \\
\hline 45 to 49 & 2 & 5 & 7 & 1 & 0 & 1 & 3 & 5 & 8 \\
\hline 50 to 54 & 2 & 1 & 3 & 0 & 2 & 2 & 2 & $\mathbf{3}$ & 5 \\
\hline 55 to 59 & 2 & 7 & 9 & 1 & 0 & 1 & 3 & 7 & 10 \\
\hline 60 to 64 & 4 & 3 & 7 & 1 & 0 & 1 & 5 & 3 & 8 \\
\hline 65 to 69 & 0 & 1 & 1 & 0 & 1 & $\mathbf{1}$ & 0 & 2 & 2 \\
\hline Over 70 & 0 & 1 & 1 & 1 & 0 & 1 & 1 & 1 & 2 \\
\hline Age unknown & 3 & 0 & 3 & 0 & 0 & 0 & 3 & 0 & 3 \\
\hline Total...... & 116 & 66 & 182 & 24 & 5 & 29 & 140 & 71 & 211 \\
\hline
\end{tabular}

* Including one white child aged 2, sex unknown. 
TABle 13.-The Distribution of Initial Attacks of Pellagra in Different Years, According to Race, Sex and Age at Time of Onset, by Five-Year Age Periods-(Continued)

\begin{tabular}{|c|c|c|c|c|c|c|c|c|c|}
\hline \multirow{2}{*}{ Age } & \multicolumn{3}{|c|}{ White } & \multicolumn{3}{|c|}{ Colored } & \multicolumn{3}{|c|}{ Both Races } \\
\hline & Female & Male & Total & Female & Male & Total & Female & Male & Total \\
\hline 1913 & & & & & & & & & \\
\hline 0 to 4 & 13 & 10 & 23 & 0 & 0 & 0 & 13 & 10 & 23 \\
\hline 5 to 9 & 9 & 11 & 20 & 0 & 1 & 1 & 9 & 12 & 21 \\
\hline 10 to 14 & 4 & 6 & 10 & 0 & 0 & 0 & 4 & 6 & 10 \\
\hline 15 to 19 & 6 & 2 & 8 & 2 & 1 & 3 & 8 & 3 & 11 \\
\hline 20 to 24 & 24 & 4 & 28 & 4 & 1 & 5 & 28 & 5 & 33 \\
\hline 25 to 29 & 27 & 4 & 31 & 4 & 2 & 6 & 31 & 6 & 37 \\
\hline 30 to 34 & 27 & 1 & 28 & 6 & 0 & 6 & 83 & 1 & 34 \\
\hline 35 to 39 & 15 & 5 & 20 & 4 & 2 & 6 & 19 & 7 & 26 \\
\hline 40 to 44 & 9 & 2 & 11 & 2 & 0 & 2 & 11 & 2 & 13 \\
\hline 45 to 49 & 5 & 4 & 9 & 1 & 1 & 2 & 6 & 5 & 11 \\
\hline 50 to 54 & 6 & 5 & 11 & 1 & 1 & 2 & 7 & 6 & 13 \\
\hline 55 to 59 & 3 & 0 & 3 & 0 & 1 & 1 & 3 & 1 & 4 \\
\hline 60 to 64 & 4 & 2 & 6 & 0 & 3 & 3 & 4 & 5 & 9 \\
\hline 65 to 69 & 0 & 2 & 2 & 0 & 0 & 0 & o & 2 & 2 \\
\hline Over 70 & 1 & · & 1 & 0 & 0 & 0 & 1 & 0 & 1 \\
\hline Age unknown & 1 & 1 & 2 & 1 & 0 & 1 & 2 & 1 & 3 \\
\hline Total...... & 154 & 59 & 213 & 25 & 13 & 38 & 179 & 72 & 251 \\
\hline 1914 & & & & & & & & & \\
\hline 0 to 4 & 10 & 10 & 20 & 0 & 1 & $\mathbf{1}$ & 10 & 11 & 21 \\
\hline 5 to 9 & 18 & 15 & 33 & 0 & 1 & 1 & 18 & 16 & 34 \\
\hline 10 to 14 & 5 & 4 & 9 & 0 & 0 & 0 & 5 & 4 & 9 \\
\hline 15 to 19 & 4 & 1 & 5 & 4 & 0 & 4 & 8 & 1 & 9 \\
\hline 20 to 24 & 17 & 1 & 18 & 7 & 0 & 7 & 24 & 1 & 25 \\
\hline 25 to 29 & 13 & 2 & 15 & 3 & 0 & 3 & 16 & 2 & 18 \\
\hline 30 to 34 & 12 & 5 & 17 & 3 & 0 & 3 & 15 & 5 & 20 \\
\hline 35 to 39 & 9 & 5 & 14 & 2 & 2 & 4 & 11 & 7 & 18 \\
\hline 40 to 44 & 10 & 2 & 12 & 2 & 0 & 2 & 12 & 2 & 14 \\
\hline 45 to 49 & 6 & 1 & 7 & 3 & 0 & 3 & 9 & 1 & 10 \\
\hline 50 to 54 & 3 & 5 & 8 & 1 & 1 & 2 & 4 & 6 & 10 \\
\hline 55 to 59 & 2 & 2 & 4 & 0 & 1 & 1 & 2 & 3 & 5 \\
\hline 60 to 64 & 1 & 3 & 4 & 0 & 0 & 0 & 1 & 3 & 4 \\
\hline 65 to 69 & 2 & 1 & 3 & 1 & 1 & 2 & 3 & 2 & 5 \\
\hline Over 70 & 1 & 3 & 4 & 0 & 0 & 0 & 1 & 3 & 4 \\
\hline Age unknown & 2 & 1 & 3 & 0 & 0 & 0 & 2 & 1 & 3 \\
\hline Total.... & 115 & 61 & 176 & 26 & 7 & 33 & 141 & 68 & 209 \\
\hline
\end{tabular}


periods, are still too detailed to give an immediate impression of the differences. The marked increase in pellagra up to 1911 and the somewhat slower increase since that time have been commented upon. Attention has also been called to the indication that relatively more negroes have been attacked in recent years. We wish, in this place, to direct especial attention to the age distribution.

TABLE 14.-Summary of Age Distribution of Initial Attacks IN DifFERENT YeARS

\begin{tabular}{|c|c|c|c|c|c|c|c|}
\hline & \multicolumn{6}{|c|}{ Age } & \multirow{2}{*}{ Tota } \\
\hline & 0 to 9 & 10 to 14 & 15 to 19 & 20 to 49 & Over 50 & Unknown & \\
\hline Before $1908 . \ldots \ldots \ldots$ & 1 & 0 & 5 & 39 & 12 & 0 & 57 \\
\hline $1908 \ldots \ldots \ldots \ldots \ldots \ldots$ & 2 & 0 & 1 & 16 & 0 & 1 & 20 \\
\hline $1909 \ldots \ldots \ldots \ldots \ldots \ldots$ & 2 & 0 & 3 & 33 & 18 & 1 & 57 \\
\hline $1910 \ldots \ldots \ldots \ldots \ldots \ldots$ & 12 & 1 & 14 & 80 & 30 & 4 & 141 \\
\hline $1911 \ldots \ldots \ldots \ldots \ldots \ldots$ & 29 & 10 & 16 & 142 & 33 & 4 & 234 \\
\hline $1912 \ldots \ldots \ldots \ldots \ldots \ldots$ & 43 & 10 & 14 & 114 & 27 & $\mathbf{3}$ & 211 \\
\hline $1913 \ldots \ldots \ldots \ldots \ldots \ldots$ & 44 & 10 & 11 & 154 & 29 & 3 & 251 \\
\hline $1914 \ldots \ldots \ldots \ldots \ldots \ldots$ & 55 & 9 & 9 & 105 & 28 & 3 & 209 \\
\hline Total............. & 188 & 40 & 73 & 683 & 177 & 19 & 1,180 \\
\hline
\end{tabular}

TABlE 15.-Proportion of Initial Attacks in Children UNDER 12 Years of Age

\begin{tabular}{|c|c|c|c|c|c|c|c|}
\hline & $\begin{array}{c}\text { Before } \\
1910\end{array}$ & 1910 & 1911 & 1912 & 1913 & 1914 & Total \\
\hline Total incident pellagrins..... & 134 & 141 & 234 & 211 & 251 & 209 & 1,180 \\
\hline Incident pellagrins under 12 years... & 5 & 13 & 33 & 48 & 51 & 62 & 212 \\
\hline Per cent. .............. & 3.7 & 9.2 & 14.1 & 22.7 & 20.3 & 29.7 & 18.0 \\
\hline
\end{tabular}

The striking differences in age distribution of initial attacks of pellagra are shown in Table 14 . In the early years, up to 1910, there were in the series only five cases in children out of a total of 134 cases, or 3.7 per cent. The ratio between initial attacks in children under 12 years and total initial attacks for each year after 1909 is shown in Table 15. It is evident that the proportion of children attacked by pellagra has increased very much since 1909 and that the proportion was greatest in 1914, when nearly 30 per cent. of the new cases were in children. This increase is in part only apparent because of the lack of attention to pellagra in children during the years previous to 1912 , 
but in a considerable degree, we believe, it represents a real increase in the proportion of children attacked by the disease. The actual number of children attacked shows a progressive increase each year to 1914 , in which year sixty-two children are known to have contracted the disease.

It is well recognized that endemic areas of pellagra in noninstitutional populations are characterized by the presence of pellagrous children. This point has been emphasized by Sambon. ${ }^{7}$ Our observa. tions of pellagra have also convinced us that the sporadic cases of pellagra and the first cases in a community are almost certain to occur in adults. The appearance of the disease in children, unless they are recent arrivals, at once suggests that the disease has gained a local foothold and that undoubted new cases are actually originating in the locality. In adults the actual place and time of origin is much less certain. We have in our series of cases several pellagrins in whom a recurrence appeared after two or more years of freedom from diagnostic symptoms and there is one instance of definite severe attack of pellagra in a woman, aged 61 , in the year 1913, who gives a very clear history of similar attacks in the summers of 1893, 1894 and 1895, with complete absence of symptoms for eighteen years. Incidentally, it may be mentioned that this old woman recovered from the 1913 attack and has remained free from the eruption in 1914 and 1915. The occurrence of such cases as this calls into question to some extent the decision concerning place of origin of the disease in adults who have changed their place of abode. In children, on the other hand, the length of previous life is shorter and in most instances the individuals have remained within a relatively small area throughout life. We are inclined, also, to believe that the incubation period of pellagra is shorter and more uniform in children.

The rapid and progressive increase of pellagra in children in Spartanburg County may therefore be regarded as additional evidence of the rather recent extension of the disease in this area and as an indication that pellagra has been and is even now becoming more firmly established as an endemic disease of this locality. In other words, more homes and more families are now afflicted with this disease than in previous years.

INCIDENCE OF PELLAGRA PER 10,000 POPULATION

The population of Spartanburg County, according to the U. S. Census, ${ }^{8}$ was 65,560 in 1900 and 83,465 in 1910 . If this increase continued at the same arithmetical rate after 1910 , there has been added

7. Sambon, L. W.: Progress Report on the Investigation of Pellagra, Jour. Trop. Med., 1910, xiii, 271, 287, 305, 319.

8. Thirteenth Census of the United States, 1910, iii, 664. 
to this population 7,162 individuals from 1910 to 1914 , and the estimated population in 1914 would be therefore 90,626 . The same census shows that the colored population of the county was 21,167 in 1900 and 26,410 in 1910 . The colored population in 1914, estimated in the same way, would be 28,507 . We have been able to obtain directly from the Census Bureau, through courtesy of the U. S. Department of Commerce, more detailed statistics of the exact distribution, according to race, sex and age, of the population under 20 years of age, as well as for the age periods 20 to 44 years, and over 45 years. These data were printed in our first progress report. ${ }^{9}$ The U. S. Census ${ }^{10}$ for 1910 also shows the composition of the population of the whole state according to race, sex and age by five-year age periods to age 65 . and beyond that by decades. Assuming that the age distribution in the whole state was not significantly different from the age distribution in Spartanburg County, we have divided the known county groups from age 20 to 44 and the known county groups of age 45 and over into five-year and ten-year age periods in the same proportion. Then by applying the formula for the arithmetic increase to each group of the total population, male and female, and to each group of the colored population, male and female, we have calculated their distribution by age periods in 1914. The distribution of the white population, that is, all not colored, has then been obtained by difference. The resulting data doubtless indicate the number of individuals of each race for each age period in the county in 1914 as accurately as is possible in the absence of an actual census taken in that year. Certainly they are sufficiently accurate for our present purpose of estimating the relative incidence of pellagra in various age periods in relation to age and sex. These data are shown in Table 16.

The ratio of total recorded incident attacks of pellagra up to the end of 1914, for each race and sex in each age period, to the respective population of the county in 1914 is shown in Table 17, expressed as incident cases per 10,000 of population. The figures represent total recorded cases in the county and not incidence per year, the total number of cases considered here $(1,180)$ being more than four times the number recorded as originating in any one year (251 in 1913). The data of these tables are presented graphically in Figure 6 . These pictures are different from those shown in Figures 2, 3, 4 and 5, because here the number of pellagrins at each age period has been divided by the total population of that age period, and of course the total population is largest in the earliest age period and tends to dimin-

9. Siler, J. F., and Garrison, P. E.: An Intensive Study of the Epidemiology of Pellagra: Report of Progress, Am. Jour. Med. Sc., 1913, cxlvi, 44; First Progress Report, 1913, p. 19.

10. Thirteenth Census of the United States, 1910, iii, 654. 
ish progressively to old age. Thus one finds that the twenty-five cases in white men in the age period 55 to 59 represent an incidence of 325 per 10,000 population at this age, whereas the forty-nine cases in the age period 5 to 9 represent an incidence of only 119 per 10,000 population at this age. The incidence rates for the white race for ages beyond

TABle 16.-Population of Spartanburg County in 1914 by Five-Year Age Periods to Age 65 and Subsequently by Decades, Calculated from Data of U. S. Census of 1910 and 1900

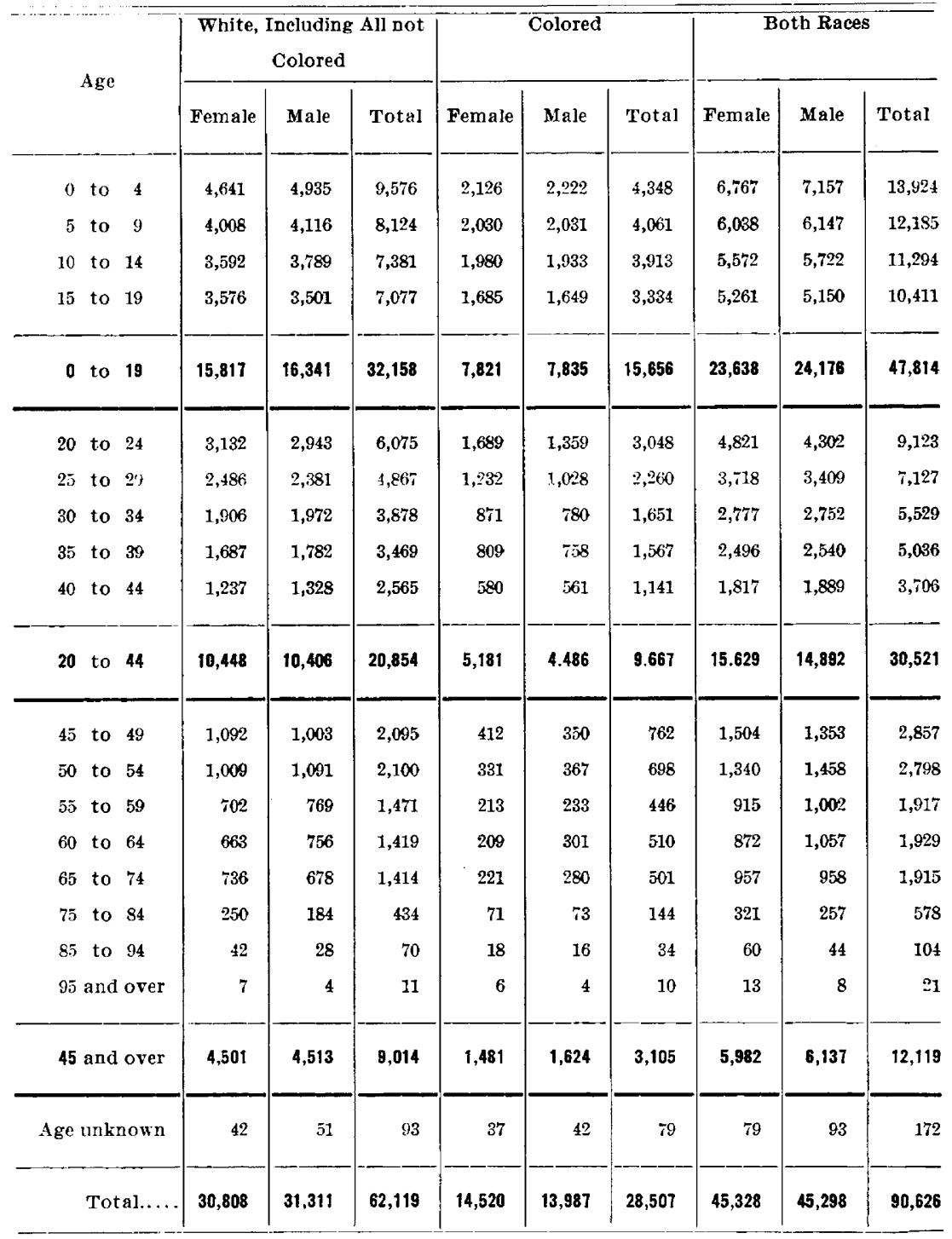


TABle 17.-Relative Incidence of Pellagra in Respect to Race, Sex and Age at Onset, Based on Total Recorded Pellagrins up to Oct. 15, 1914, and Population of the County in 1914 Estimated by Computation from U. S. CENSUS OF 1900 AND 1910

\begin{tabular}{|c|c|c|c|c|c|c|c|c|c|}
\hline \multirow[b]{3}{*}{ Age } & \multicolumn{8}{|c|}{ White Race } & \\
\hline & \multicolumn{3}{|c|}{ Female } & \multicolumn{3}{|c|}{ Male } & \multicolumn{3}{|c|}{ Total } \\
\hline & $\begin{array}{l}\text { Popu- } \\
\text { lation, } \\
1914\end{array}$ & $\begin{array}{l}\text { Re- } \\
\text { corded } \\
\text { Pella- } \\
\text { grins }\end{array}$ & $\begin{array}{c}\text { Inci- } \\
\text { dence } \\
\text { per } \\
10,000\end{array}$ & $\begin{array}{c}\text { Popu- } \\
\text { lation, } \\
1914\end{array}$ & $\begin{array}{l}\text { Re- } \\
\text { corded } \\
\text { Pella- } \\
\text { grins }\end{array}$ & $\begin{array}{c}\text { Inci- } \\
\text { dence } \\
\text { per } \\
10,000\end{array}$ & $\begin{array}{c}\text { Popu- } \\
\text { lation, } \\
1914\end{array}$ & $\begin{array}{l}\text { Re- } \\
\text { corded } \\
\text { Pella. } \\
\text { grins }\end{array}$ & $\begin{array}{c}\text { Inei- } \\
\text { dence } \\
\text { per } \\
10,000\end{array}$ \\
\hline 0 to 4 & 4,641 & 41 & 88 & 4,835 & 42 & 85 & 9,576 & $84^{*}$ & 88 \\
\hline 5 to 8 & 4,008 & 47 & 117 & 4,116 & 49 & 119 & 8,124 & 96 & 118 \\
\hline 30 to 14 & 3,592 & 18 & 50 & 3,789 & 22 & 58 & 7,381 & 40 & 54 \\
\hline 15 to 19 & 3,576 & 47 & 131 & 3,501 & 8 & 23 & 7,077 & 55 & 78 \\
\hline 0 to 19 & 15,817 & 153 & 97 & 16,341 & 121 & 74 & 32,158 & $275^{*}$ & 86 \\
\hline 20 to 24 & 3,132 & 106 & 338 & 2,943 & 10 & 34 & 6,075 & 116 & 191 \\
\hline 25 to 29 & 2,486 & 111 & 447 & 2,381 & 14 & 59 & 4,867 & 125 & 257 \\
\hline 30 to 34 & 1,906 & 102 & 535 & 1,972 & 17 & 86 & 3,878 & 119 & 307 \\
\hline 35 to 40 & 1,687 & 72 & 427 & 1,782 & 23 & 129 & 3,469 & 95 & 274 \\
\hline 40 to 44 & 1,237 & 58 & 469 & 1,328 & 25 & 188 & 2,565 & 83 & 394 \\
\hline 20 to 44 & 10,448 & 449 & 430 & 10,406 & 89 & 86 & 20,854 & 538 & 258 \\
\hline 45 to 49 & 1,092 & 29 & 266 & 1,003 & 19 & 189 & 2,095 & 48 & 229 \\
\hline 50 to 54 & 1,009 & 26 & 258 & 1,021 & 24 & 220 & 2,100 & 50 & 238 \\
\hline 55 to 59 & 702 & 18 & 256 & 769 & $2 \overline{5}$ & 325 & $1,4 i 1$ & 43 & 292 \\
\hline 60 to 64 & 663 & 15 & 226 & 756 & 17 & 225 & 1,419 & 32 & 226 \\
\hline 65 to 74 & 736 & 6 & 82 & 678 & 12 & 177 & 1,414 & 18 & 127 \\
\hline 75 to 84 & 250 & 2 & 80 & 184 & 3 & 163 & 434 & 5 & 115 \\
\hline 85 to 94 & 42 & 1 & 238 & 28 & 0 & 0 & 70 & 1 & 143 \\
\hline Over 95 & 7 & 0 & 0 & 4 & 0 & o & 11 & 0 & 0 \\
\hline 45 and over & 4,501 & 97 & 216 & 4,513 & 100 & 222 & 9,014 & 197 & 219 \\
\hline Age unknown & 42 & 13 & $\ldots \ldots$ & 51 & 4 & $\cdots \cdots$ & 93 & 17 & $\ldots \ldots$ \\
\hline Total..... & 30,808 & 712 & 231 & 31,311 & 314 & 103 & 62,119 & $1,027^{*}$ & 165 \\
\hline
\end{tabular}

* Including one child, aged 2, whose sex was not ascertained. 
Table 17.-Relative Incidence of Pellagra in Respect to Race, Sex and Age at Onset, Based on Total Recorded Pellagrins up to OCt. 15, 1914, and Population of the County in 1914 Estimated by Computation From U. S. Census of 1900 and $1910-($ Continued)

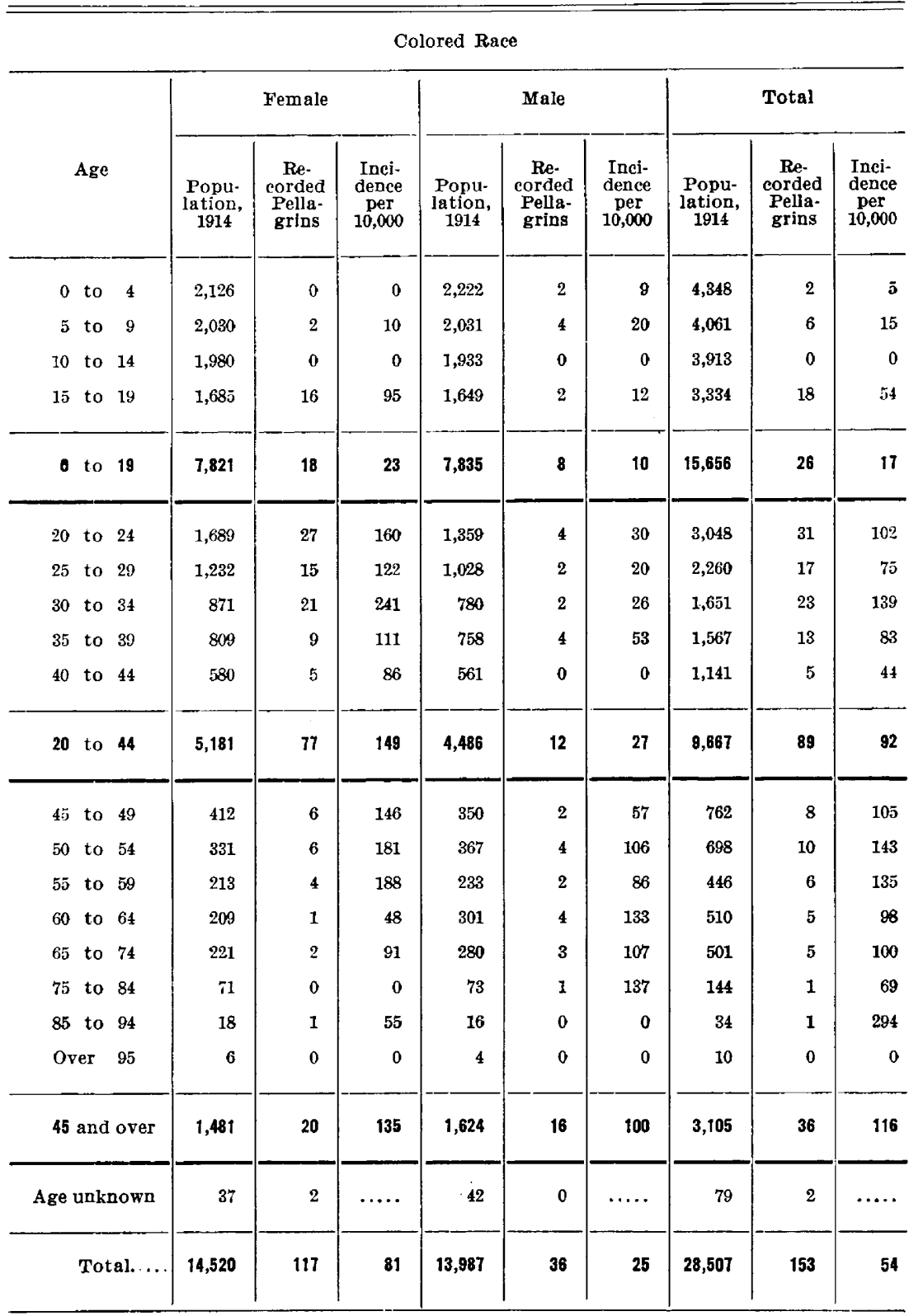




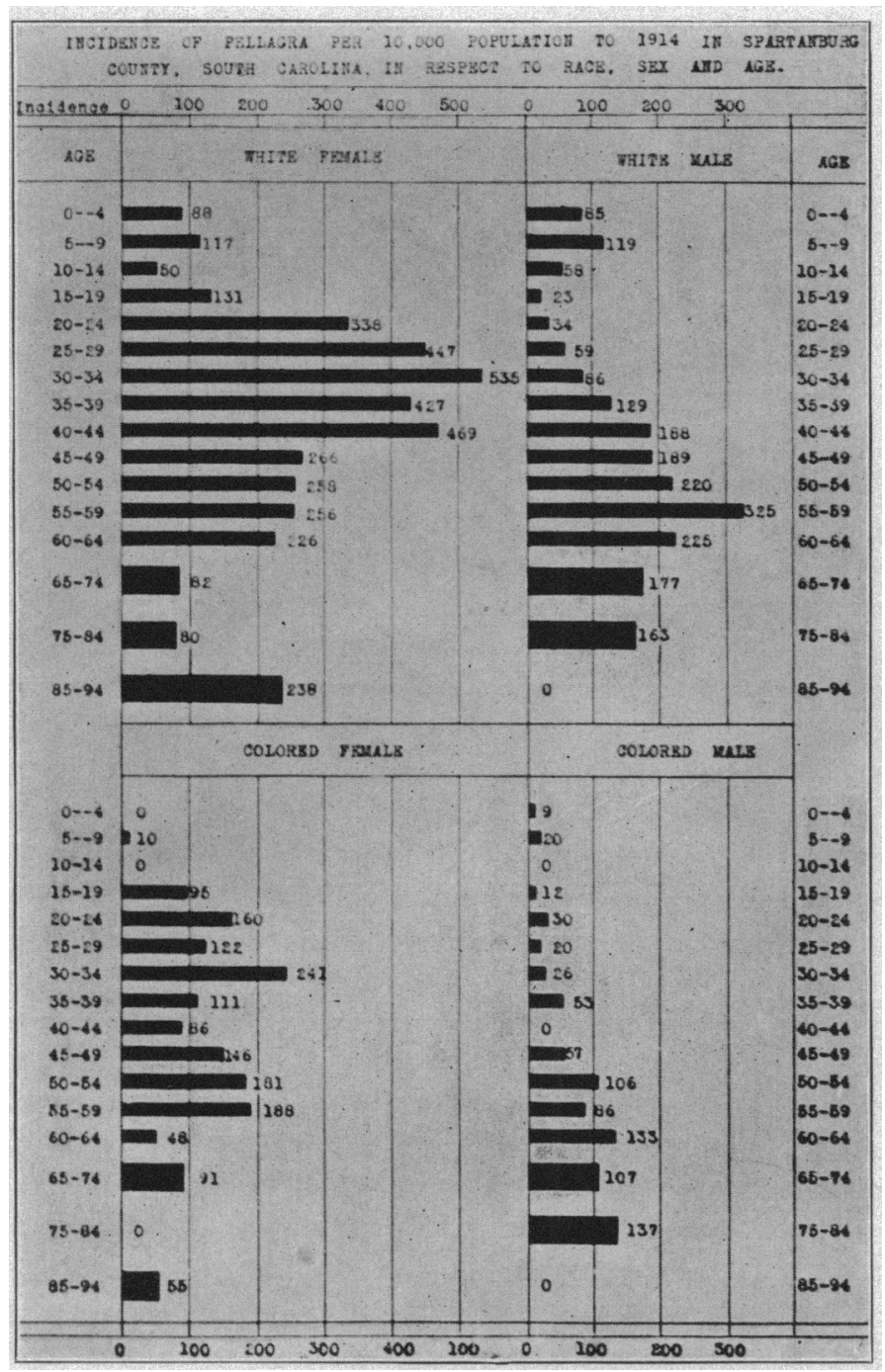

Fig. 6.-The incidence per 10,000 population has been computed from the calculated population of Spartanburg County in 1914 and the total recorded cases of pellagra in each five-year age period according to age at onset of the initial erythema. The broader columns after age of 65 apply to ten-year-age groups. The incidence per 10,000 for each age group is also indicated by the number placed at the end of the column. 
age 75 and for the negro race beyond age 45 have little or no significance because of the very small groups of population.

In every instance there is a peak in the age period 5 to 9 followed by a fall in the period 10 to 14 . In the next period, 15 to 19 years, the rise is sharp in the white female population, but especially sharp in the colored male and female. In fact it is in the ten years from 15 to 24 that the incidence of pellagra in negroes, both men and women, approaches most nearly the incidence rate of the disease in the white race of this county. In white women the rate ascends rapidly to reach the enormous incidence of 535 per 10,000 population in the age period 30 to 34 , after which it gradually declines. The rate in white men ascends much more gradually, but in a progressive manner, reaching an incidence of 325 per 10,000 in the age period 55 to 59 years. In the negroes the incidence rate is everywhere lower than in the white race. For the negro women there is a rapid increase beginning at age 15 and reaching its height in the period 30 to 34 years, this being followed by a rapid decline and an irregular incidence beyond age 45 , where the number of individuals is small. In negro men the number of individuals is so small that comparisons of different age periods are hardly warranted. The incidence rate on the whole is lower than that for any other of the three race-sex groups. Only after age 60 is there a distinct indication of a higher incidence in negro men than in negro women.

In this connection it may be mentioned that, next to negro children of both sexes, the adult negro men are most effectively segregated from social relationships with the white race in Spartanburg County, especially that portion of the white race which lives in the chief endemic foci of pellagra, namely, the cotton-mill villages. The adult negro man is to a very large extent a day laborer or a field worker in the open air, and his home is in general a cabin or a poorly constructed house, isolated on a farm or segregated in the negro quarter of a village or city. To this rule there are some exceptions, but they are relatively not numerous. The negro women also work in the field in many instances in addition to performing their household duties. Most of them are at some time employed by white families for domestic duties, some as house servants, but more in the capacity of washerwomen. The homes of the negro women are the same as the homes of the negro men and even when engaged as cooks and waitresses it is customary for the negro women to return to their homes at night. The data concerning food will, of course, be considered in a separate paper. It will suffice here to point out that the diet of the negroes is much inferior in quality, quantity and variety to that of the white race in this county.

In our opinion the relatively lower pellagra incidence in negroes in this county is due chiefly to their relative segregation from pei- 
lagrins. They live in poorer houses, eat an inferior diet and are, as a whole, in much worse financial condition than the white race. On the other hand, they are socially segregated, their homes are for the most part either isolated cabins or are grouped in negro quarters of the city, town or village. Pellagra is not so persistently present among them as among the white race, furthermore, because the negro pellagrins die much more promptly than do the white pellagrins. The facts observed here in Spartanburg County in regard to racial and age differences in pellagra incidence indicate very strongly that poverty and poor diet are, as has long been known, factors of great moment in determining death rate from pellagra in those attacked, but that, as far as the original onset of the disease is concerned, they are of importance only in conjunction with close association with antecedent pellagrins or residence in an endemic area of the disease.

SUM MARY

1. The number of recognized incident cases of pellagra in Spartanburg County has increased progressively each year since 1907, very rapidly to 1911 and at a less rapid rate to 1914 .

2. The death rate in year of initial attack was 15.8 per cent. for the total 1,180 recorded cases. There is no definite indication of a progressive change in the death rate in recent years, although it was apparently higher previous to 1911 .

3. The disease has attacked the white race more than the negroes in this county, but in recent years there has been a slow but progressive increase in the ratio of incident negro pellagrins to incident white pellagrins.

4. The death rate in initial attack has been 41.8 per cent. for negroes and 12 per cent. for the white race.

5. Pellagra was very rarely observed under the age of 1 year. It was not so rare in the second year and fairly common in the age period from 2 to 12 years. The death rate in initial attack has been low in children.

6. Evidence of residence very close to an antecedent pellagrin has ustually been quite clear in the cases of infantile pellagra.

7. The milk of pellagrous mothers cannot be regarded as the cause or the vehicle of the cause of pellagra in infants.

8 . The age period 12 to 16 years is relatively free from initial attacks of pellagra.

9. After age 16 years pellagra incidence rises rapidly in women and the rise is especially sharp in colored women. In the latter group the death rate has been high, 46.7 per cent., in year of onset in the age period 16 to 20 years. 
10. From age 20 to age 50 years, the number of women attacked by pellagra gradually diminishes and the number of men attacked gradually increases, so that the two sexes are approximately equal in this respect at age 50 . In old age the onset of pellagra has been slightly more common in men in this population.

11. The death rate in first attack in white women over 20 years of age has been 11.9 per cent., increasing progressively from 4.6 per cent. in the third decade to 47.6 per cent. in the seventh decade of life. The death rate for analogous groups of white men, colored women and colored men has been 21.2 per cent., 40.2 per cent. and 50 per cent., respectively, with a slight tendency for the death rate to increase with age in all groups.

12. Pellagrins with onset under the age of 12 years were only 3.7 per cent. of the total recorded cases previous to 1910, but the proportion has increased to 29.7 per cent. of the total recorded onsets in the year 1914. These observations corroborate the other evidence of a distinct progressive increase of pellagra in this county in recent years.

13. The incidence per 10,000 population has been 231 for white female population, 103 for white male, 81 for colored female and 25 for colored male. In the age period 10 to 14 years the incidence is low in all groups. In white female population it is highest in the age period 30 to 34 years, namely 535 per 10,000 ; in white male, in the age period 55 to 59 , namely 325 per 10,000 ; in colored female 241 per 10,000 in age period 30 to 34 ; in colored male 133 per 10,000 in age period 60 to 64 .

14. The lower incidence rate and the higher death rate for those attacked have occurred in negroes in conjunction with greater poverty of this race and a diet poorer in quality, quantity and variety. Incidence has been lowest in the sex and age groups of negroes most completely segregated from white pellagrins. 